\title{
Review \\ An Overview of the Latest Advances in the Catalytic Synthesis of Glycerol Carbonate
}

\author{
Debora Procopio (1) and Maria Luisa Di Gioia *(1)
}

check for

updates

Citation: Procopio, D.; Di Gioia, M.L. An Overview of the Latest Advances in the Catalytic Synthesis of Glycerol Carbonate. Catalysts 2022, 12, 50. https://doi.org/10.3390/catal12010050

Academic Editors: Francesco Ruffo and Roberto Esposito

Received: 4 December 2021

Accepted: 30 December 2021

Published: 2 January 2022

Publisher's Note: MDPI stays neutral with regard to jurisdictional claims in published maps and institutional affiliations.

Copyright: (C) 2022 by the authors. Licensee MDPI, Basel, Switzerland. This article is an open access article distributed under the terms and conditions of the Creative Commons Attribution (CC BY) license (https:// creativecommons.org/licenses/by/ $4.0 /)$.
Dipartimento di Farmacia e Scienze della Salute e della Nutrizione, Dipartimento di Eccellenza L. 232/2016, Edificio Polifunzionale, Università della Calabria, 87036 Rende, Italy; debora.procopio@unical.it

* Correspondence: ml.digioia@unical.it

Abstract: In recent years, the development of renewable energy alternatives to traditional fossil fuels has become one of the major challenges all over the world, due to the decline of fossil fuel reserves and their effect on global warming. Biodiesel has become a popular alternative energy source to reduce gas emissions compared to traditional fossil fuels. According to statistics, a nine-fold increase in global biofuel production between 2000 and 2020 was observed. However, its production generates a large amount of glycerol as a by-product, posing an environmental problem when disposed directly in landfills or by incineration. Therefore, low-value glycerol should be converted into high valueadded derivatives. As glycerol carbonate is one of the most important derivatives of glycerol, this review aims to discuss the studies over the last ten years about glycerol carbonate synthetic methods, including the typical routes such as phosgene, esterification reaction, urea, oxidative and direct carbonylation as well as several rare synthetic procedures. At the same time, it summarizes the different catalytic reaction systems of each route comparing the advantages and disadvantages of various catalysts and evaluating their catalytic activity. Finally, the future development of glycerol carbonate synthesis is prospected from the point of view of development, technology research and industrialization.

Keywords: glycerol; green chemistry; by-product; glycerol carbonate; catalysis

\section{Introduction}

The greenhouse effect and environmental pollution caused by traditional fossil energy, together with the energy depletion crisis, have become the major challenges facing the sustainable development of human society [1]. The price of the development and progress of human society at this stage is the consumption of a large amount of resources and energy, and the discharge of a large amount of waste, destroying the natural environment. The importance of accelerating the development of renewable energy alternatives to traditional fossil fuels has become increasingly prominent. Biodiesel is a type of biomass energy, mainly obtained through the transesterification of animal and vegetable oils with methanol, with good development prospects as it offers the advantages of green energy, low sulfur, and low pollution; thus, over the last few decades, the biodiesel industry is one of the booming industries in European, North American, and South Asian countries [2-4]. In order to maintain the sustainable development of the natural and social environment on which mankind depends, it is necessary to make green improvements to various existing industrial production, including the process for obtaining biodiesel [5].

In 2020, global biofuel production levels reached 1677 thousand barrels of oil equivalent per day, in stark comparison to the 187 thousand barrels of oil equivalent per day that was produced in 2000. The global biofuels market is expected to reach a market size of 153.8 billion U.S. dollars by 2024 [6].

However, every $1000 \mathrm{~kg}$ of biodiesel produced will create as a by-product about $100 \mathrm{~kg}$ of glycerol [7]. In fact, the transesterification of oils in biodiesel production process yields 
glycerol as the main by-product. Therefore, with the large-scale production of biodiesel, how to effectively reuse glycerol has become a research focus.

In order to realize the efficient conversion of glycerol and promote the healthy and orderly development of the biodiesel industry, low-value glycerol should be converted into high value-added derivatives. At present, it is largely exploited as a starting material in different synthetic procedures, such as reduction, esterification, dehydration, carbonylation, oxidation, etherification, among others (Figure 1) [8-10].

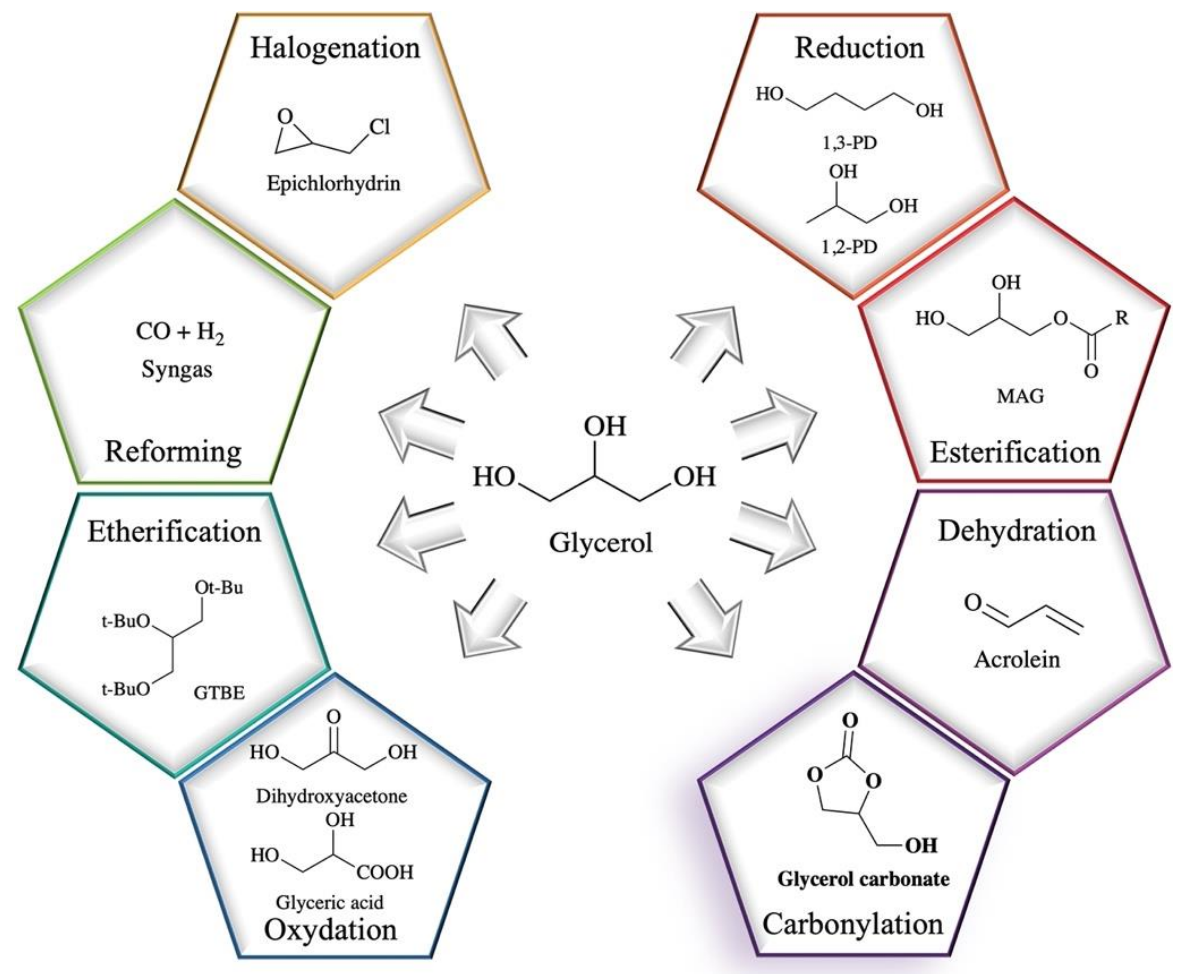

Figure 1. Main synthetic processes and high value-added chemicals obtained from glycerol valorization.

Among the many conversion products of glycerol, glycerol carbonate (GC) has been widely studied for its irreplaceable advantages. GC belongs to the family of organic carbonates that are regarded as very typical "green chemistry" products for their unique advantages in many fields, such as high boiling point solvents, pharmaceutical intermediates, and material intermediates. Therefore, the synthetic process and application of organic carbonates have now received extensive attention and study from researchers [11,12].

In particular, GC has attracted great interest because it is a very versatile raw material that has developed a research hotspot finding direct applications for the production of glycidol which is widely used in cosmetics and paints; in addition, GC is used in lithiumion battery industries as an excellent chemical solvent or as membrane coating in gas separation units; furthermore, it finds indirect applications as a monomer precursor in the manufacture of polyurethane, polycarbonates, polyglycerols, polyols, and several other polymer industries [13,14].

Therefore, this review will summarize the different synthetic procedures to afford GC, focusing on its process routes, catalytic material systems, and reaction mechanisms, while aiming specifically to point out the potential industrial application value of the process.

\section{Routes for Glycerol Carbonate Synthesis}

Nowadays, under the advocacy of a conservation-oriented and environmentally friendly society, and through a large amount of research, the method of synthesizing glycerol carbonate is developing in the direction of non-toxicity and simplicity [15]. At 
present, several of these methods have been industrialized and realized commercial value. According to industry norms and standards, no matter which method is chosen, many basic industry feasibility standards must be met, as follows [16]: When it comes to catalytic reactions, priority must be given to using cheap, easily separated, and recyclable catalysts; additionally, simple separation and purification methods should be used; the use of solvents and toxic chemicals should be avoided or reduced; high conversion rate and high selectivity should be obtained; lastly, a short reaction time would be desirable.

There are four main synthetic routes (Figure 2) reported at this stage to convert glycerol into racemic glycerol carbonate, namely (1) reaction of glycerol with phosgene, (2) carbonylation of glycerol by urea, (3) transesterification of glycerol with dimethyl carbonate or ethylene carbonate, and (4) reaction of glycerol with carbon dioxide or carbon monoxide [12,17].

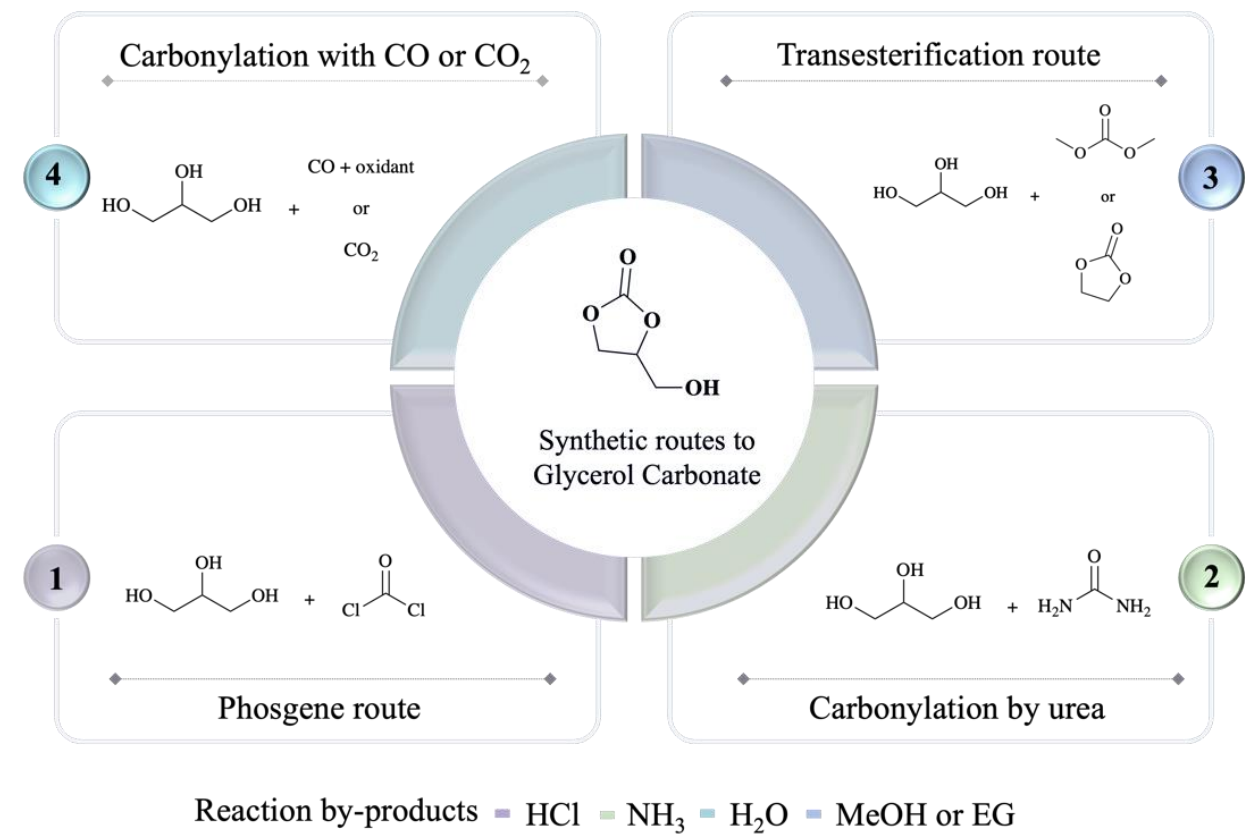

Figure 2. Main synthetic routes to glycerol carbonate.

\section{Phosgene Route}

As early as 1948, the method to produce glycerol carbonate was developed by Strain [18] by using glycerol and phosgene (Figure 2).

The catalysts used in this route are some common alkali metal salts and alkaline-earth metal salts, such as $\mathrm{NaOH}, \mathrm{Na}_{2} \mathrm{CO}_{3}, \mathrm{Ca}(\mathrm{OH})_{2}$. Subsequent literature reported that pyridine, which is basic due to the lone electron pair on the nitrogen atom accepting protons, can also catalyze the reaction of glycerol and phosgene to produce GC [17].

Although the phosgene route has good reaction performance, it not only needs to be carried out at a very low temperature $\left(-70^{\circ} \mathrm{C}\right)$, but also the raw materials are highly toxic chemical products, which are not suitable for transportation and pollute the environment. At the same time, the by-product $\mathrm{HCl}$ will corrode equipment, and the complicated process of preparing glycerol carbonate leads to a long operation cycle, which is contrary to the concept of contemporary green chemical industry and belongs to the elimination process $[13,19,20]$.

\section{Carbonylation by Urea}

Synthesis of GC from glycerol and urea in the presence of a suitable catalyst is an attractive method of production, also known as the urea method. The advantages of this reaction system are as follows: the raw materials glycerol and urea are non-toxic, cheap, 
and easy to obtain, no solvent is added in the reaction, the reaction conditions are mild, and the glycerol conversion rate is high [21].

The by-product of the reaction is only $\mathrm{NH}_{3}$, which can be recovered and coupled with $\mathrm{CO}_{2}$ to generate urea, realizing the indirect synthesis of GC from $\mathrm{CO}_{2}$ and glycerol. It can be argued that urea represents an activated form of $\mathrm{CO}_{2}$. The industrial process utilizes the Bosch-Meiser urea route, developed in 1922 [22]. This makes urea a green and good alternative source for carbonylation reactions. [23].

Nevertheless, in order to promote the reaction balance to shift to the right, it is necessary to continuously remove the generated ammonia gas, which will pollute the environment, under reduced pressure (40-50 mbar), thus increasing investment costs.

The reaction mechanism of the urea route has been studied extensively over the past years. Rubio-Marcos et al. [24] proposed that the hydroxyl group of glycerol attacks the carbonyl carbon atom in urea under the action of the catalyst. After the removal of ammonia gas, a ring-closure reaction will occur to produce glycerol carbonate. Nevertheless, the water loss at this stage can result in the formation of 4-(hydroxymethyl)oxazolidin-2-one as side product; furthermore, GC, after its formation, could subsequently react with urea to yield (2-oxo-1,3-dioxolan-4-yl)methyl carbamate, as shown in Scheme 1.

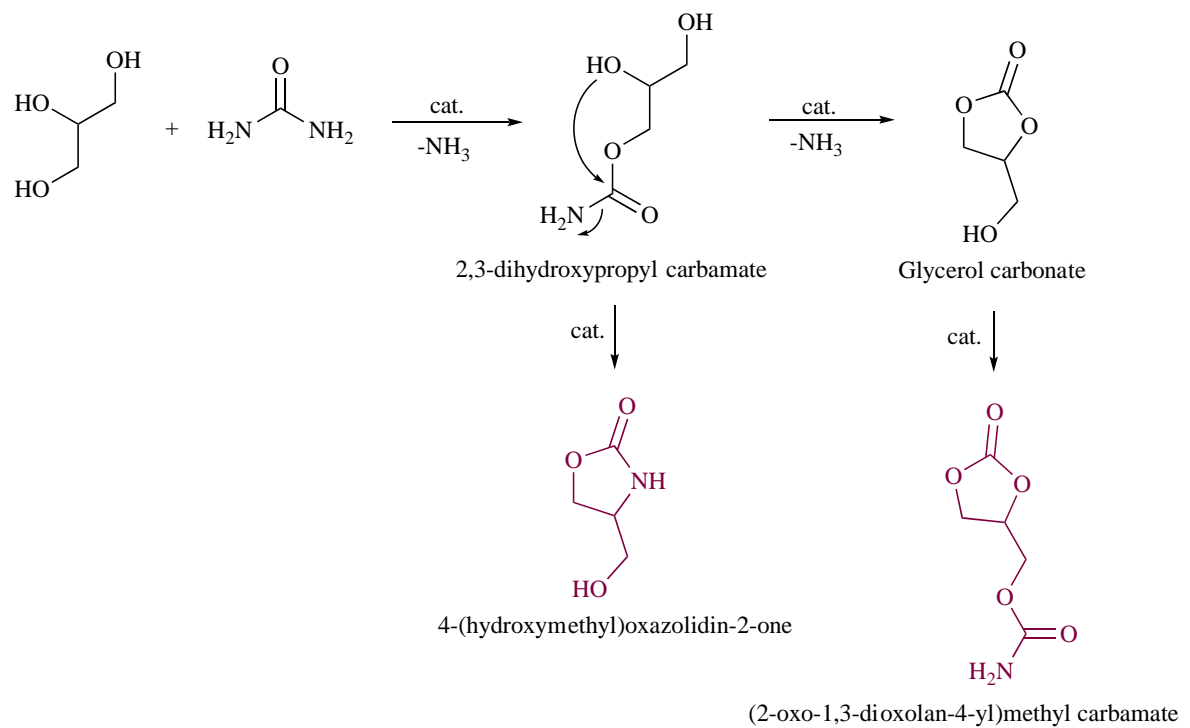

Scheme 1. Rubio-Marcos proposed reaction pathway of urea and glycerol.

Although it is difficult to establish a clear and general reaction mechanism theoretically, some researchers have used infrared spectroscopy and other methods to explore the reaction mechanism in depth. Calvino-Casilda et al. [25] showed through real-time attenuated total reflection infrared spectroscopy that the first step is a fast step, and the second step is a slow step, that is, the step that determines the reaction time. The reaction conditions must be strictly optimized to prevent the GC and urea from continuing to react to form glycerol carbonate carbamate (Scheme 1) [26].

\subsection{Catalyst Application of Urea Route}

The GC yield of the reaction system with the urea route is low, and a catalyst must be used to obtain a higher glycerol conversion rate [27]. Consequently, the design and selection of catalysts are particularly critical. The following catalysts bearing Lewis acidic sites seem to produce satisfying results with significant yields: manganese sulfate, zinc oxide, zinc sulfate, zinc chloride, metal oxides $\left(\mathrm{CaO}, \mathrm{La}_{2} \mathrm{O}_{3}, \mathrm{MgO}, \mathrm{ZrO}_{2}, \mathrm{Al}_{2} \mathrm{O}_{3}\right), \gamma$-zirconium phosphate, mixed oxides HTc- $\mathrm{Zn}$ derived from hydrotalcite, $\mathrm{Co}_{3} \mathrm{O}_{4} / \mathrm{ZnO}$ nanodispersion, gold-supported zeolite ZSM-5 catalyst, lanthanum oxide as a solid base catalyst, polymersupported ionic liquids, and samarium-exchanged heteropolytungstate [13]. They are 
mainly divided into the following four categories of catalysts: metal salt, ionic liquid, solid acid or base, and zinc-based solid catalysts (Figure 3).

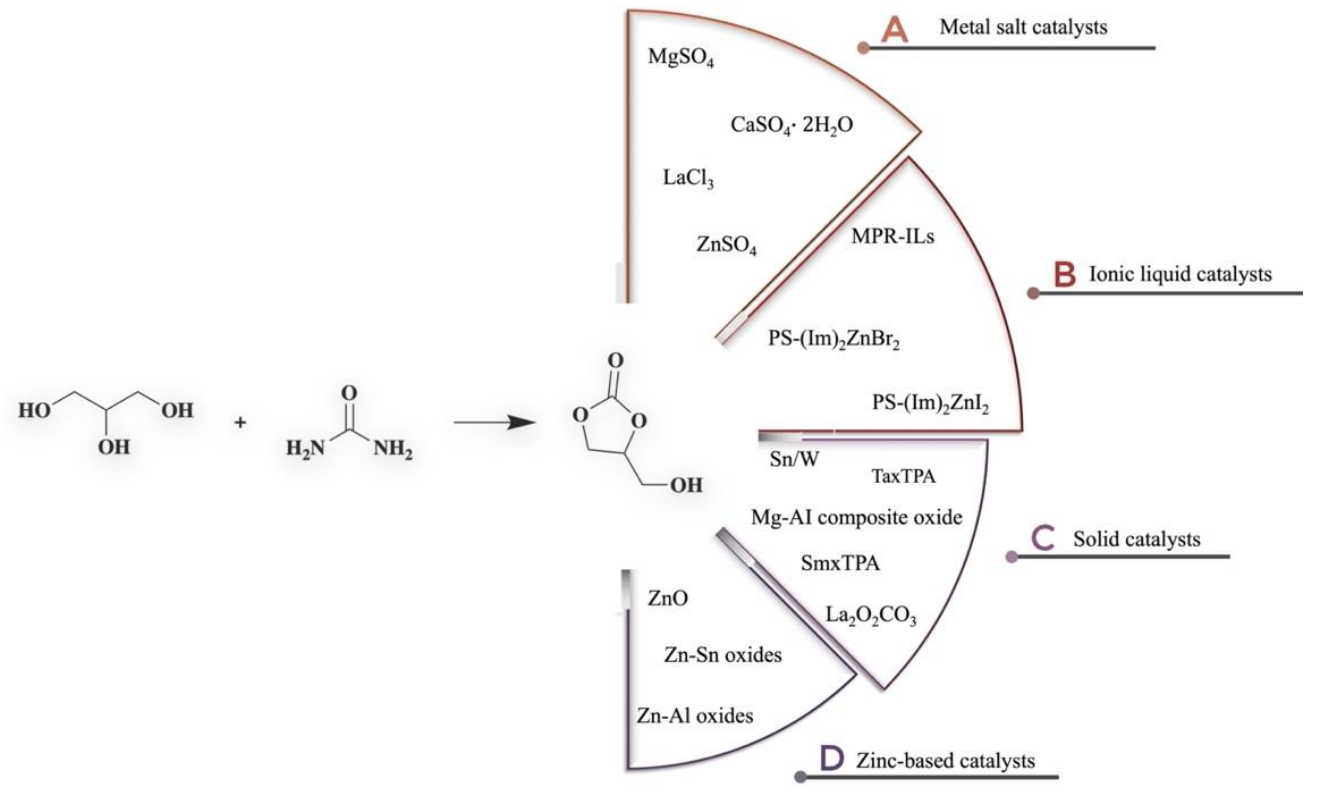

Figure 3. Main categories of catalysts in GC synthesis through urea route.

\subsubsection{Metal Salt Catalysts}

Park et al. [28] explored the catalytic activity of a series of zinc-based catalysts $\left(\mathrm{ZnBr}_{2}\right.$, $\mathrm{ZnI}_{2}$, etc.). $\mathrm{ZnCl}_{2}$ showed good catalytic activity resulting completely soluble in the reaction system during the reaction.

In 2013, Fujita et al. [29] used glycerol and urea to synthesize GC by choosing a solid catalyst containing zinc. The author pointed out that $\mathrm{Zn}^{2+}$ in the reaction solution would react with urea to form a $\mathrm{Zn}^{2+}$-containing chelate $\left(\mathrm{NH}_{3}\right)_{2}-\mathrm{Zn}(\mathrm{NCO})_{2}$, and then react with glycerol; the catalytic mechanism is shown in Scheme 2 taking $\mathrm{ZnO}$ as an example.

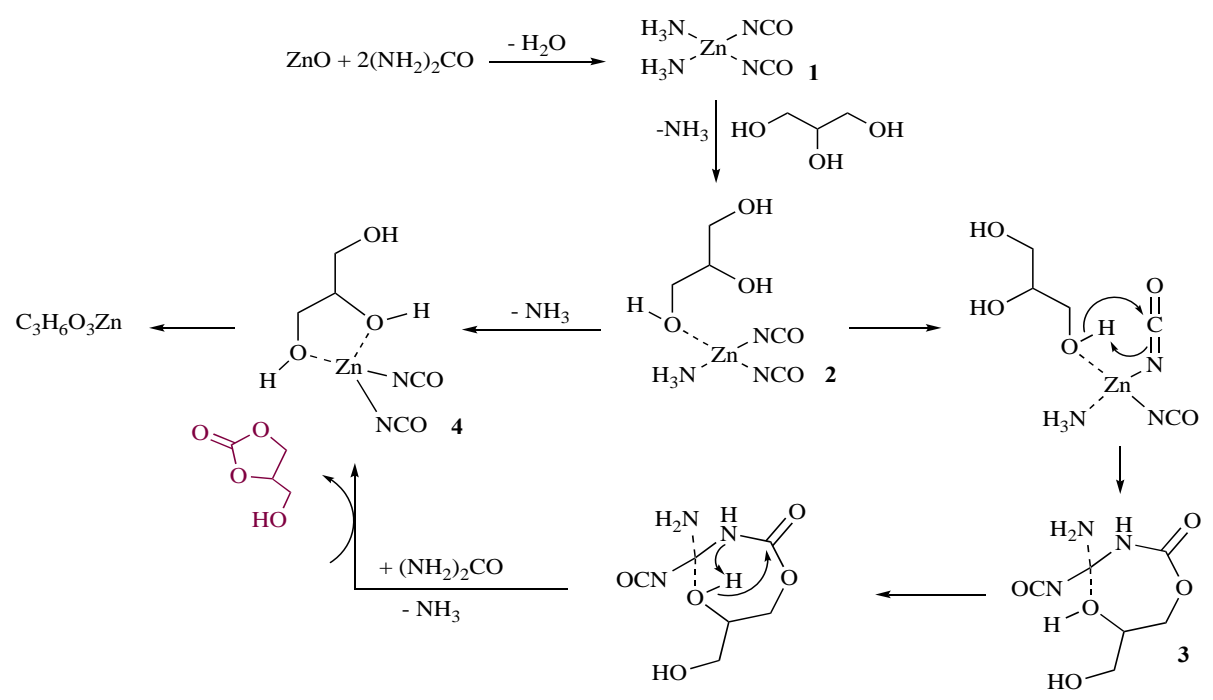

Scheme 2. Mechanism of reaction of glycerol with urea catalyzed by zinc.

In 2015, Zuhaimi et al. [30] reported for the first time the carbonylation reaction of glycerol and urea on a gypsum-based $\left(\mathrm{CaSO}_{4} \cdot 2 \mathrm{H}_{2} \mathrm{O}\right)$ heterogeneous catalyst. The catalyst composed of $\beta-\mathrm{CaSO}_{4}$ phase showed the highest catalytic activity for the reaction, 
enabling to produce a $92.8 \%$ glycerol conversion rate, $90.1 \%$ selectivity and $83.6 \%$ GC yield; furthermore, gypsum catalyst is easy to recover and can be recycled. In the same year, Wang et al. [31] used different lanthanum compounds $\left(\mathrm{La}\left(\mathrm{NO}_{3}\right)_{3}\right.$ and $\mathrm{LaCl}_{3}$, etc.) to catalyze the synthesis of GC from urea and glycerol. Among them, the best catalytic effect is when $\mathrm{LaCl}_{3}$ was used as the catalyst because not only $\mathrm{LaCl}_{3}$ can be completely dissolved in the reaction system during the reaction, but as already demonstrated, the anion $\mathrm{Cl}^{-}$also had a certain catalytic activity (Scheme 3). After reacting at $150{ }^{\circ} \mathrm{C}$ for $3 \mathrm{~h}$, the glycerol conversion rate was $95.4 \%$, and the GC selectivity was $99.7 \%$

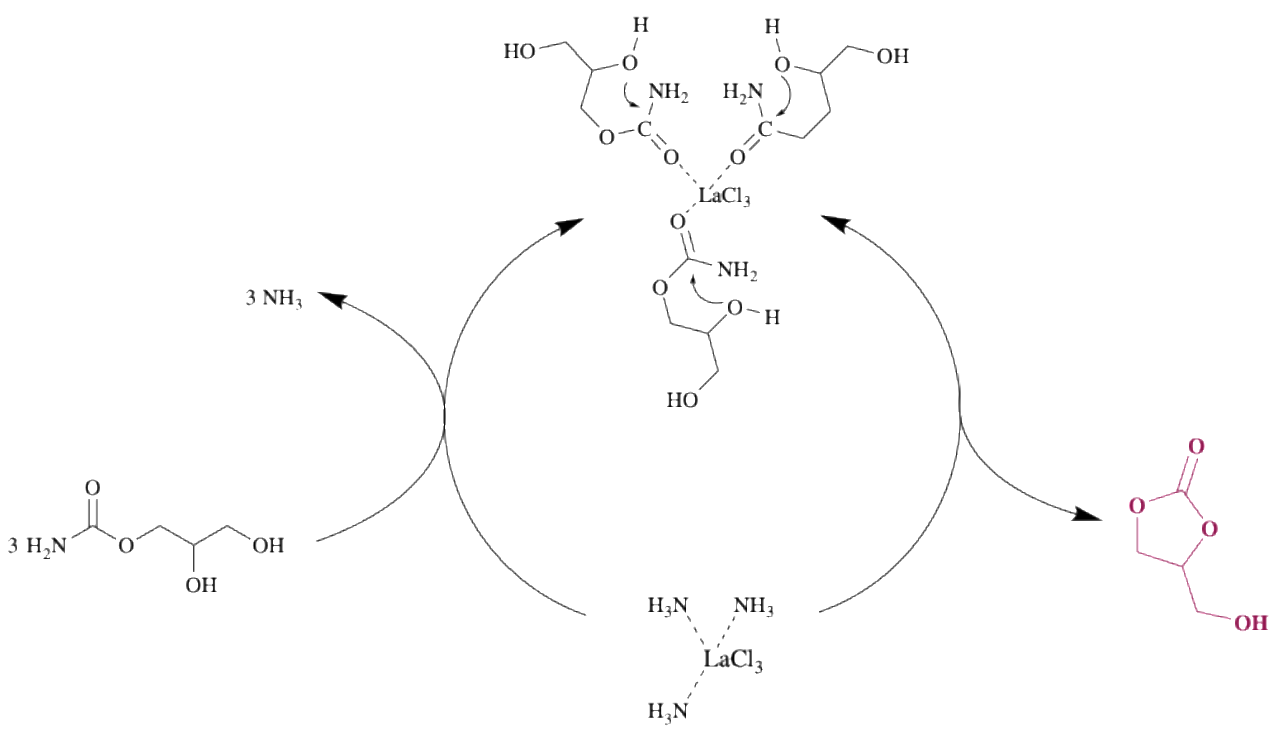

Scheme 3. Reaction mechanism catalyzed by $\mathrm{LaCl}_{3}$.

Very recently, Rode et al. [32] proposed a solvent-free carbonylation of glycerol with urea to GC achieved over a heterogeneous $\mathrm{Cu}-\mathrm{Zn}$ mixed oxide catalyst. Various $\mathrm{Cu}-\mathrm{Zn}$ mixed oxide catalysts were prepared using different $\mathrm{Cu}: \mathrm{Zn}$ compositions, and a $\mathrm{Cu} / \mathrm{Zn}$ ratio of 2:1, glycerol-urea 1:1 molar ratio and $145^{\circ} \mathrm{C}$ reaction temperatures were found to be the best reaction conditions to succeed in glycerol conversion of $86 \%$ and obtain complete selectivity towards $\mathrm{GC}$. The $\mathrm{CuO}-\mathrm{ZnO}$ catalyst could be recycled up to three times without losing its initial activity.

Although the research on metal salt catalysts is earlier and their ability to catalyze the reaction of glycerol and urea to synthesize GC is stronger, since they are typical homogeneous catalysts, the separation of products and the recovery of catalysts are the shortcomings that are difficult for the above-mentioned catalytic systems to overcome, which limits their further industrial application to a certain extent. Thus, these metal salt compounds are not the ideal catalysts for this route.

\subsubsection{Ionic Liquid Catalysts}

Chen et al. [33] compared a series of ionic liquid catalysts with different $\mathrm{pH}$ and found that a catalyst with a suitable anion and cation composition is the key to an efficient synthesis. This is because the cation of the ionic liquid can activate urea and the anion can activate hydroxyl groups of glycerol through a hydrogen bonding interaction, thus enabling the selective synthesis of GC. Compared with the traditional metal salt homogeneous catalysts, IL's catalytic ability is higher [34]. However, due to the complicated preparation, high preparation cost, and low stability, these shortcomings greatly limit their applications.

In order to overcome the above-mentioned problems, Kim et al. loaded metal saltcontaining ionic liquids on polymer carriers and found that zinc-containing ionic liquids have the highest catalytic activity. First, Kim et al. [35] prepared polystyrene-based Merrifield peptide resin-supported ionic liquid catalysts (MPR-ILs); when catalyzing the 
glycerol-urea reaction, the glycerol conversion rate was 78.3\%, and the GC selectivity was $94.4 \%$. Later, the same group [36] found that the metal-containing imidazolium salts PS-(Im) ${ }_{2} \mathrm{ZnBr}_{2}$ and PS-(Im) ${ }_{2} \mathrm{ZnI}_{2}$ supported by PS had glycerol conversion rates of $65.8 \%$ and $71.7 \%$, respectively, and the GC selectivity were $72.3 \%$ and $84.1 \%$, respectively. Such a catalyst is easy to separate and recover and can be recycled. Then, Kim [37] prepared an acid-base catalyst 1-(2-Hydroxyethyl)imidazole $/ \mathrm{ZnCl}_{2}$ that can catalyze the reaction of glycerol and urea at $140{ }^{\circ} \mathrm{C}$, up to a $92.7 \%$ glycerol conversion rate and $93.4 \%$ GC selectivity.

Although the catalytic stability has been significantly improved, the preparation of these supported catalysts is expensive and complicated; in addition, it is not suitable for large-scale applications. At the same time, it should be noted that the above-mentioned research results have laid the foundation for the development of highly efficient heterogeneous catalysts.

\subsubsection{Solid Acid and Basic Catalysts}

Because there are carbonyl oxygen atoms and amino nitrogen atoms in the urea molecule, they can be adsorbed and activated by the acidic sites of the solid acid catalyst. Jagadeeswaraiah et al. [38] introduced $\mathrm{Zn}$ into the heteropolytungstate. Compared with a single heteropolytungstic acid, the Zn-containing heteropolyacid catalyst had a higher catalytic ability, and the activity depended on the introduced zinc ion content. Further research showed that the increase in Lewis acidic sites on the catalyst surface is beneficial to the synthesis of GC. Moreover, the stability of these catalysts was relatively high, and their activity remained basically unchanged after repeated use. In addition, Jagadeeswaraiah et al. [39] also revealed the influence of $\mathrm{Sn} / \mathrm{W}$ atomic ratio on the selective synthesis of GC. When the $\mathrm{Sn} / \mathrm{W}$ ratio of the catalyst was 2:1, the catalytic performance result was optimal. Under the best reaction conditions, the selectivity of GC could reach $95.3 \%$.

Kumar et al. [40] prepared $\mathrm{Sm}^{3+}$ and $\mathrm{Zn}^{2+}$ exchanged tungstophosphoric acid catalysts (SmxTPA and ZnxTPA). Different studies have found that the activity of this catalyst is related to its acidity, and the acidity of the catalyst is related to the content of Sm or Zn. Among them, Sm0.66 TPA and $\mathrm{Zn}_{1}$ TPA catalysts showed the highest acidity and the highest catalytic activity. Babu et al. [41] investigated the tungstophosphoric acid catalyst (TaxTPA) exchanged by tantalum, and the $\mathrm{NH}_{3}$-TPD analysis results revealed that the catalyst had high acidity. Ta0.4TPA catalyzes the reaction of glycerol and urea, obtaining about $71.0 \%$ glycerol conversion and about 100\% GC selectivity. In 2016, Jagadeeswaraiah et al. [42] prepared a catalyst for the synthesis of GC from urea route by loading $\mathrm{WO}_{3}$ on $\mathrm{TiO}_{2}$ by impregnation method. They pointed out that the acidity of the catalyst depended on the loading of $\mathrm{WO}_{3}$ on $\mathrm{TiO}_{2}$ and the calcination temperature. The optimal conditions were that calcination of $15 \%$ $\mathrm{WO}_{3}$ at $500{ }^{\circ} \mathrm{C}$, could achieve $73 \%$ glycerol conversion, and the GC selectivity was close to $100 \%$, and the catalyst can be reused without significant loss of activity. They also studied the influence of the carrier on the conversion rate of glycerol. The activity of different carriers was in the order of $\mathrm{Al}_{2} \mathrm{O}_{3}<\mathrm{ZrO}_{2}<\mathrm{Nb}_{2} \mathrm{O}_{5}<\mathrm{MoO}_{3}<\mathrm{SiO}_{2}<\mathrm{TiO}_{2}$.

Srikanth et al. [43] first loaded the cesium-containing compound on the carrier (CsPW) by impregnation method, then obtained a composite Sn-CsPW catalyst by calcination Cs-exchanged heteropolyacid catalysts functionalized with Sn. The mechanism of SnCsPW catalyzing the reaction of glycerol and urea is shown in Scheme 4, the reaction was conducted at $140{ }^{\circ} \mathrm{C}$ and $83 \%$ GC selectivity was obtained.

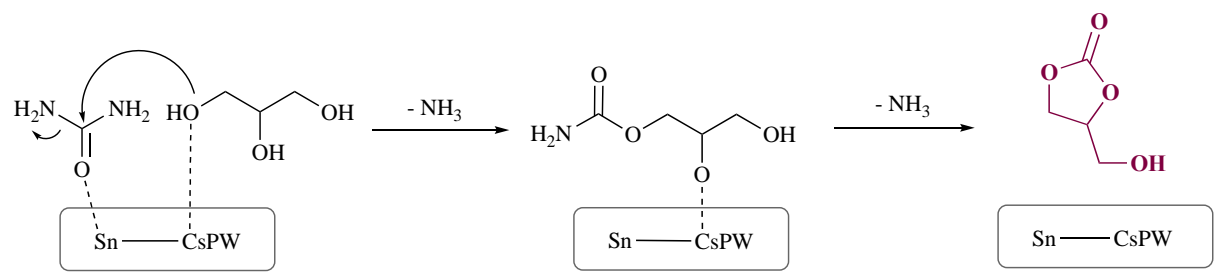

Scheme 4. Mechanism of Sn-CsPW catalyzing the reaction of glycerol and urea. 
Recently, Reddy et al. [44] studied the urea route using $\mathrm{SnO}_{2}$-based solid acid catalysts. The incorporation of $\mathrm{MoO}_{3}$ and $\mathrm{WO}_{3}$ species into the $\mathrm{SnO}_{2}$ drastically improved its structural, textural, and acidic properties. It was found that $\mathrm{MoO}_{3} / \mathrm{SnO}_{2}$ catalyst showed an excellent glycerol conversion with higher GC yield when compared to $\mathrm{WO} / \mathrm{SnO}$ and $\mathrm{SnO}_{2}$ catalysts. The superior activity performance of the $\mathrm{MoO}_{3} / \mathrm{SnO}_{2}$ could be ascribed to the existence of a greater number of acidic sites, smaller particle size, and bigger specific surface area (Scheme 5).

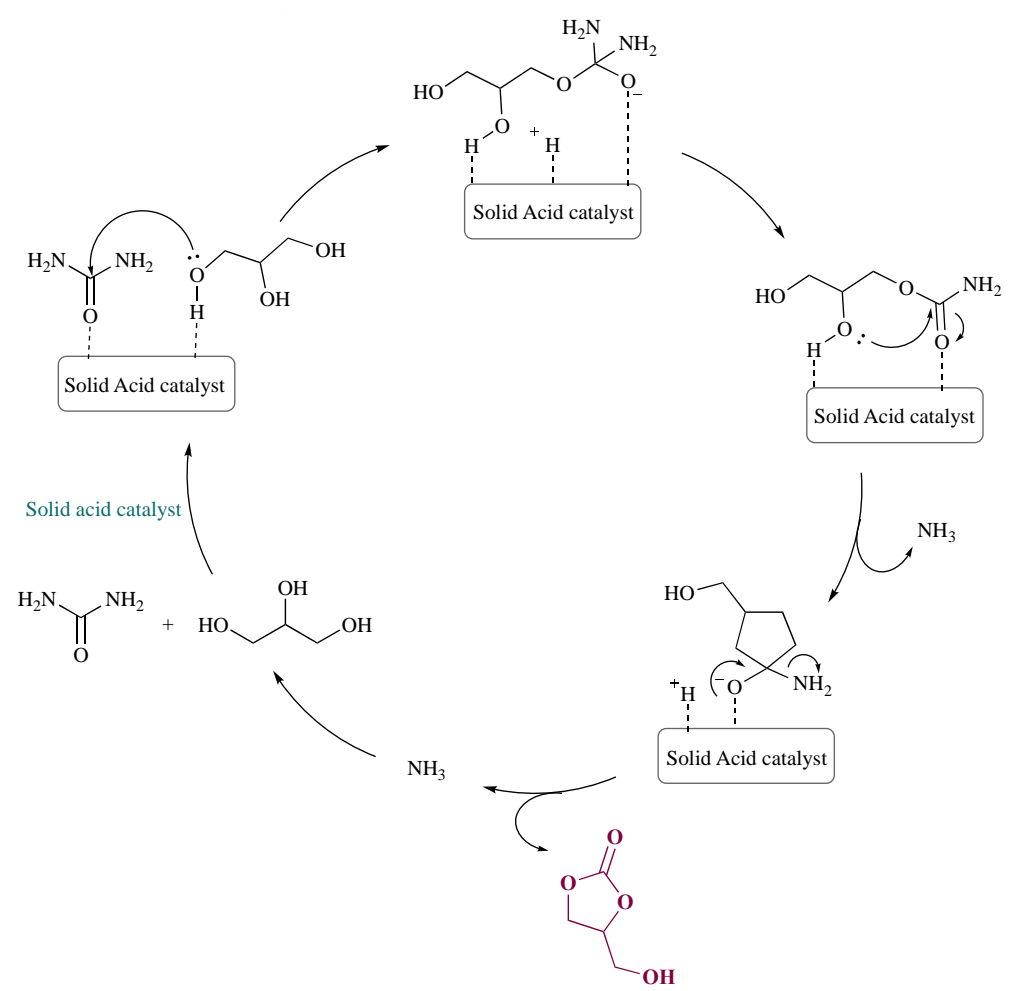

Scheme 5. General mechanism of solid acid catalyst in the urea route to GC.

In summary, the solid acid catalyst has better catalytic performance, and its catalytic stability is significantly improved compared with the metal salt and ionic liquid catalysts discussed above. However, the reaction activity of these catalysts still cannot meet the requirements of industrialized production of GC, and certain methods are needed to improve their catalytic activity.

The glycerol molecule can be activated by the Lewis alkaline sites of the catalyst. For example, Wang et al. [45] obtained a series of lanthanum oxide catalysts and pointed out that the increase in the strength of basic alkaline sites on the catalyst surface is beneficial to the synthesis of GC, and that the catalyst has an appropriate amount of $\mathrm{La}_{2} \mathrm{O}_{2} \mathrm{CO}_{3}$ to improve the catalytic activity. Under the optimal reaction conditions, GC selectivity can exceed 98\%. Lately, Lari et al. [46] prepared Mg-AI composite oxide catalyst for continuous production of GC. The results showed that the activity of the catalyst comes from its surface alkaline sites, and these catalysts present high stability during continuous production.

Compared with the above-mentioned catalysts, the outstanding advantage of the solid base catalyst is its higher catalytic stability, and it is a potential heterogeneous solid catalyst for the industrial production of GC. However, under the action of this type of catalyst, the side reactions also occur violently, reducing the selectivity of GC. Therefore, it is necessary to further modify the solid base catalyst to develop a solid base catalyst that can achieve more efficient synthesis of GC. 


\subsubsection{Zinc-Based Solid Catalysts}

It can be seen from the above discussion that zinc salts have high catalytic activity, but most of them are homogeneous catalysts, which are not conducive to the separation of products and the recovery of catalysts in industrial processes. To overcome the above shortcomings, researchers have developed many zinc-based solid catalysts to improve the stability of the catalysts. $\mathrm{ZnO}$ is the most readily available zinc-based solid catalyst. Zhang et al. [47] stated that the activity of $\mathrm{ZnO}$ is due to the suitable Lewis acidic-alkaline sites on its surface. However, Fujita et al. [29] studied the structural changes of $\mathrm{ZnO}$ during the reaction and showed that $\mathrm{ZnO}$ can easily generate zinc compounds soluble in the reaction system while activating urea [48]. Therefore, current researchers mainly prepare zinc-based composite oxides (Zn-Sn, Zn-Mg-al, Zn-Al composed oxides) to improve the stability of such catalysts [49].

In 2021, Bhanage et al. [50] developed a sustainable and economically advantageous procedure for the synthesis of $\mathrm{ZnO}$ nanomaterials under solar energy using aromatic amino acids as photo-capping agents. This calcined $\mathrm{ZnO}$ nanomaterial showed good catalytic activity in the urea route to produce GC that was yielded in $67 \%$ at $140{ }^{\circ} \mathrm{C}$ in $4 \mathrm{~h}$ (Scheme 6).

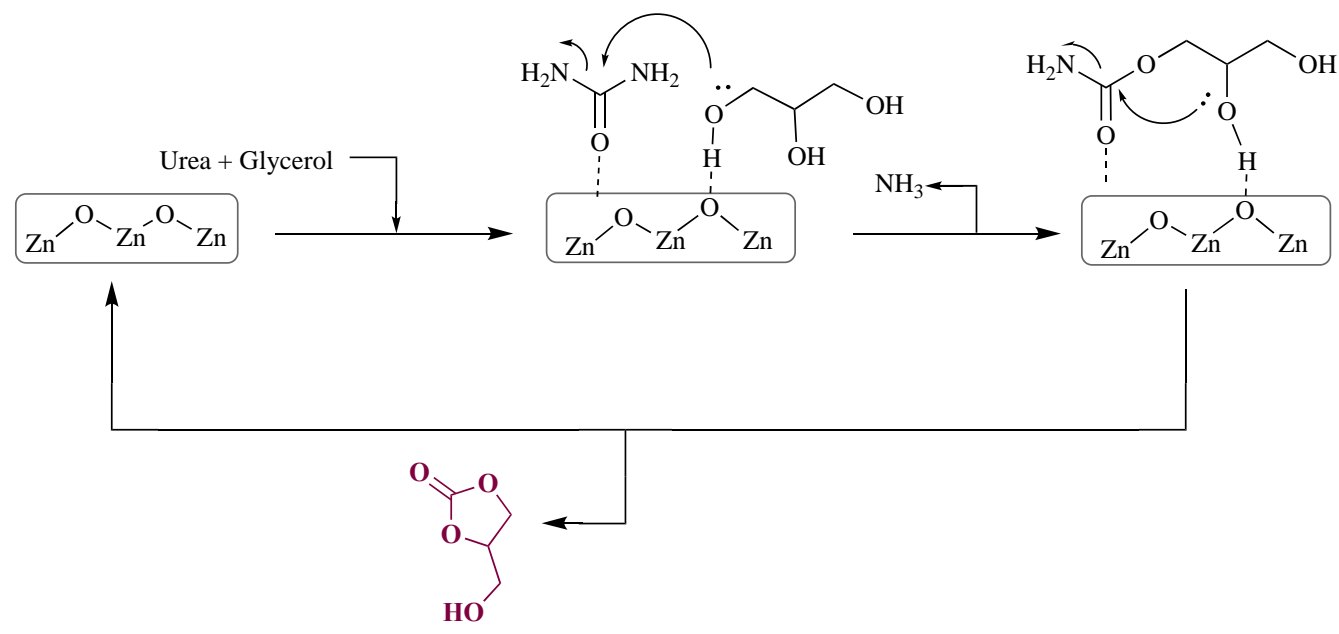

Scheme 6. Mechanism for the synthesis of GC assisted by calcined ZnO nanomaterial.

In short, zinc-based solid catalysts are currently the most widely used heterogeneous solid catalysts for GC synthesis using the urea route since they are prepared in a simple way and show high catalytic activity. However, during the catalytic process, the $\mathrm{ZnO}$ active phase easily forms a homogeneous compound soluble in the reaction system, and the $\mathrm{ZnO}$ active phase will be lost significantly. So, the stability of such catalysts is insufficient, thereby hindering its large-scale industrial application to a certain extent [42,46].

\subsection{The Future of the Urea Route}

The glycerolysis of urea represents an interesting synthetic procedure for GC that may have an industrial application. The good conversion of glycerol, the high selectivity, the easy separation of the catalyst and its full recovery, as well as the recovery of $\mathrm{NH}_{3}$ and the continuous separation of carbonate, make the methodology described very promising.

Among the reported catalysts for this route, the industrial application prospects of zinc-based solid catalysts and solid base catalysts are better [46,47]. At the same time, compared with homogeneous catalysts, heterogeneous catalysts have more research value because they are beneficial to product separation and catalyst recovery.

All in all, in the future development and design of high-efficiency heterogeneous catalysts, the goal should be to achieve the unity of high activity and high stability of the catalyst, and to clarify the role of Lewis acidic-alkaline sites on the catalyst surface in the 
activation reactants, thereby increasing the conversion rate of glycerol and the selectivity of GC (Table 1).

Table 1. Comparison of the main catalysts used in glycerolysis of urea to obtain GC.

\begin{tabular}{|c|c|c|c|c|c|}
\hline \multirow{2}{*}{ Catalyst } & \multirow{2}{*}{$\begin{array}{c}\text { Gly\% } \\
\text { Conversion }\end{array}$} & \multirow{2}{*}{$\begin{array}{c}\text { GC/\% } \\
\text { Selectivity }\end{array}$} & \multicolumn{3}{|c|}{ Reaction Conditions } \\
\hline & & & Temperature & Pressure & Time \\
\hline $\mathrm{ZnO}$ & 69.9 & 84.1 & $150^{\circ} \mathrm{C}$ & $2.7 \mathrm{kPa}$ & $2 \mathrm{~h}$ \\
\hline $\mathrm{ZnCl}_{2}$ & 80.4 & 99.7 & $150^{\circ} \mathrm{C}$ & $2.7 \mathrm{kPa}$ & $2 \mathrm{~h}$ \\
\hline $\mathrm{ZnF}_{2}$ & 76.4 & 68.5 & $150^{\circ} \mathrm{C}$ & $2.7 \mathrm{kPa}$ & $2 \mathrm{~h}$ \\
\hline $\mathrm{ZnBr}_{2}$ & 81.4 & 97.2 & $150^{\circ} \mathrm{C}$ & $2.7 \mathrm{kPa}$ & $2 \mathrm{~h}$ \\
\hline $\mathrm{ZnI}_{2}$ & 80.9 & 94.9 & $150^{\circ} \mathrm{C}$ & $2.7 \mathrm{kPa}$ & $2 \mathrm{~h}$ \\
\hline $\mathrm{LaCl}_{3}$ & 95.4 & 99.9 & $150{ }^{\circ} \mathrm{C}$ & $5 \mathrm{kPa}$ & $3 \mathrm{~h}$ \\
\hline $\mathrm{La}(\mathrm{OH})_{3}$ & 42.3 & 55.6 & $150^{\circ} \mathrm{C}$ & $5 \mathrm{kPa}$ & $3 \mathrm{~h}$ \\
\hline $\mathrm{La}\left(\mathrm{NO}_{3}\right)_{3}$ & 91.8 & 98.3 & $150^{\circ} \mathrm{C}$ & $5 \mathrm{kPa}$ & $3 \mathrm{~h}$ \\
\hline $\mathrm{La}(\mathrm{OAc})_{3}$ & 90.8 & 97.4 & $150^{\circ} \mathrm{C}$ & $5 \mathrm{kPa}$ & $3 \mathrm{~h}$ \\
\hline $\mathrm{Sm}_{0.66} \mathrm{TPA}$ & 49.5 & 85.4 & $140^{\circ} \mathrm{C}$ & - & $4 \mathrm{~h}$ \\
\hline $\mathrm{Zn}_{1} \mathrm{TPA}$ & 69.2 & 99.4 & $140^{\circ} \mathrm{C}$ & - & $4 \mathrm{~h}$ \\
\hline $\mathrm{Ta}_{0.4} \mathrm{TPA}$ & 71.0 & 99.9 & $140^{\circ} \mathrm{C}$ & - & $4 \mathrm{~h}$ \\
\hline ILs & 76.0 & 68.4 & $140^{\circ} \mathrm{C}$ & - & $4 \mathrm{~h}$ \\
\hline $\mathrm{Au} / \mathrm{ZSM}-5$ & 81.0 & 68.0 & $150^{\circ} \mathrm{C}$ & - & $4 \mathrm{~h}$ \\
\hline $\mathrm{Co}_{3} \mathrm{O}_{4} / \mathrm{ZnO}$ & 69.0 & 97.0 & $150^{\circ} \mathrm{C}$ & - & $4 \mathrm{~h}$ \\
\hline $\mathrm{La}_{2} \mathrm{O}_{3}$ & 45.2 & 98.6 & $140^{\circ} \mathrm{C}$ & $3 \mathrm{kPa}$ & $1 \mathrm{~h}$ \\
\hline $\mathrm{SnO}_{2} / \mathrm{WO}_{3}$ & 52.1 & 95.3 & $140^{\circ} \mathrm{C}$ & - & $4 \mathrm{~h}$ \\
\hline $\mathrm{WO}_{3}-\mathrm{TiO}_{2}$ & 73.0 & 99.9 & $140^{\circ} \mathrm{C}$ & - & $4 \mathrm{~h}$ \\
\hline $\mathrm{ZnO} / \mathrm{SnO}_{2}$ & 96.0 & 99.6 & $155^{\circ} \mathrm{C}$ & - & $4 \mathrm{~h}$ \\
\hline MPR-ILs/ZnO & 78.3 & 94.4 & $140^{\circ} \mathrm{C}$ & $15 \mathrm{kPa}$ & $3 \mathrm{~h}$ \\
\hline $\mathrm{PS}-(\mathrm{Im})_{2} \mathrm{ZnBr}_{2}$ & 65.8 & 72.3 & $140^{\circ} \mathrm{C}$ & $15 \mathrm{kPa}$ & $6 \mathrm{~h}$ \\
\hline PS-(Im) ${ }_{2} \mathrm{ZnI}_{2}$ & 71.7 & 84.1 & $140^{\circ} \mathrm{C}$ & $15 \mathrm{kPa}$ & $6 \mathrm{~h}$ \\
\hline$(\mathrm{HEIm})_{2} \mathrm{ZnCl}_{2}$ & 92.7 & 93.4 & $140^{\circ} \mathrm{C}$ & $15 \mathrm{kPa}$ & $6 \mathrm{~h}$ \\
\hline $\mathrm{Zn} / \mathrm{MCM}-41$ & 75.0 & 98.0 & $145^{\circ} \mathrm{C}$ & - & $5 \mathrm{~h}$ \\
\hline Zn-FAU & 94.6 & 98.0 & $150{ }^{\circ} \mathrm{C}$ & - & $3 \mathrm{~h}$ \\
\hline $\mathrm{SiW}_{12} / \mathrm{MCM}-41$ & 75.0 & 77.0 & $150^{\circ} \mathrm{C}$ & - & $8 \mathrm{~h}$ \\
\hline HTc-Zn & 82.0 & 88.0 & $145^{\circ} \mathrm{C}$ & $4 \mathrm{kPa}$ & $5 \mathrm{~h}$ \\
\hline $\mathrm{HT}(\mathrm{Mg} / \mathrm{Zn} / \mathrm{Al})$ & 89.8 & 93.2 & $145^{\circ} \mathrm{C}$ & $4 \mathrm{kPa}$ & $5 \mathrm{~h}$ \\
\hline $\mathrm{ZnSn}(\mathrm{OH})_{6}$ & 98.0 & 99.6 & $165^{\circ} \mathrm{C}$ & - & $5 \mathrm{~h}$ \\
\hline Gypsum & 92.8 & 86.6 & $150^{\circ} \mathrm{C}$ & - & $4 \mathrm{~h}$ \\
\hline
\end{tabular}

\section{CO Oxidative Carbonylation Route}

Carbonylation is a type of reaction in which carbonyl groups are introduced into the framework of organic compounds. This is an important method for preparing carbonyl compounds such as aldehydes and ketones [51]. Carbon monoxide is one of the most important carbonylation reagents. The carbonylation method is used to directly synthesize GC using $\mathrm{CO}, \mathrm{O}_{2}$ and glycerol as raw materials under the action of a catalyst.

The reaction system is generally carried out under the conditions of $0.5-5 \mathrm{MPa}$ and $70-170^{\circ} \mathrm{C}$. The reaction raw materials are cheap and easy to obtain, the reaction by-product is only water, and the atom utilization rate is high. It can also realize the synthesis of the target product in one step without intermediate reaction steps. Under certain reaction conditions, both $\mathrm{CO}_{2}$ and $\mathrm{CO}$ can be used as carbonylation reagents to react with glycerol to generate $\mathrm{GC}$, but compared with $\mathrm{CO}_{2}, \mathrm{CO}$ has higher chemical activity. In the reaction of glycerol and CO to produce GC, the most common oxidant is oxygen, which can afford GC in high yield under relatively mild conditions [52].

Therefore, such a route realizes the sustainable conversion of cheap and easily available raw materials into high value-added chemicals.

\subsection{Application of Catalyst for CO Oxidation Carbonylation}

Initially, Teles [53] used $\mathrm{O}_{2}$ as the oxidant for the reaction under high temperature and high pressure conditions. The catalysts used mainly included transition metal compounds 
of groups IB, IIB, and VIIIB. Studies have shown that among the metal salts used, the catalyst with halogen as anion had the highest catalytic efficiency, and copper chloride had the best catalytic effect, and the GC yield was as high as 65\%. In 2010, Hu et al. [54] used $\mathrm{PdCl}_{2}$ as a catalyst and $\mathrm{KI}$ as a co-catalyst to obtain GC at $140{ }^{\circ} \mathrm{C}$ for $2 \mathrm{~h}$. When the catalyst content was $0.25 \%$, the product yield was as high as $92 \%$, and the selectivity could reach 99\%. Later, Casiello et al. [55] used $\mathrm{CuCl}_{2}$ as a catalyst and pyridine as a co-catalyst to obtain GC after $3 \mathrm{~h}$ reaction at $130{ }^{\circ} \mathrm{C}$. The glycerol conversion rate exceeded $92 \%$ and the selectivity exceeded $93 \%$.

In addition to oxygen, other oxidants can also oxidize $\mathrm{CO}$ and react with glycerol to form GC. Mizuno et al. [56,57] reported a synthetic strategy based on CO oxidative carbonylation (Scheme 7), that used sulfur or selenium in the "triethylamine + DMF" solvent to pre-activate glycerol, and then under the action of $\mathrm{CuBr}_{2}, \mathrm{CO}$ react with the pre-activated intermediate. In this case, the yield of GC was $69 \%$. However, it was necessary to add selenium and glycerol in an equal molar ratio during this reaction. Obviously, the amount of catalyst is not economical and generates a large amount of by-products, which greatly limits its large-scale application.

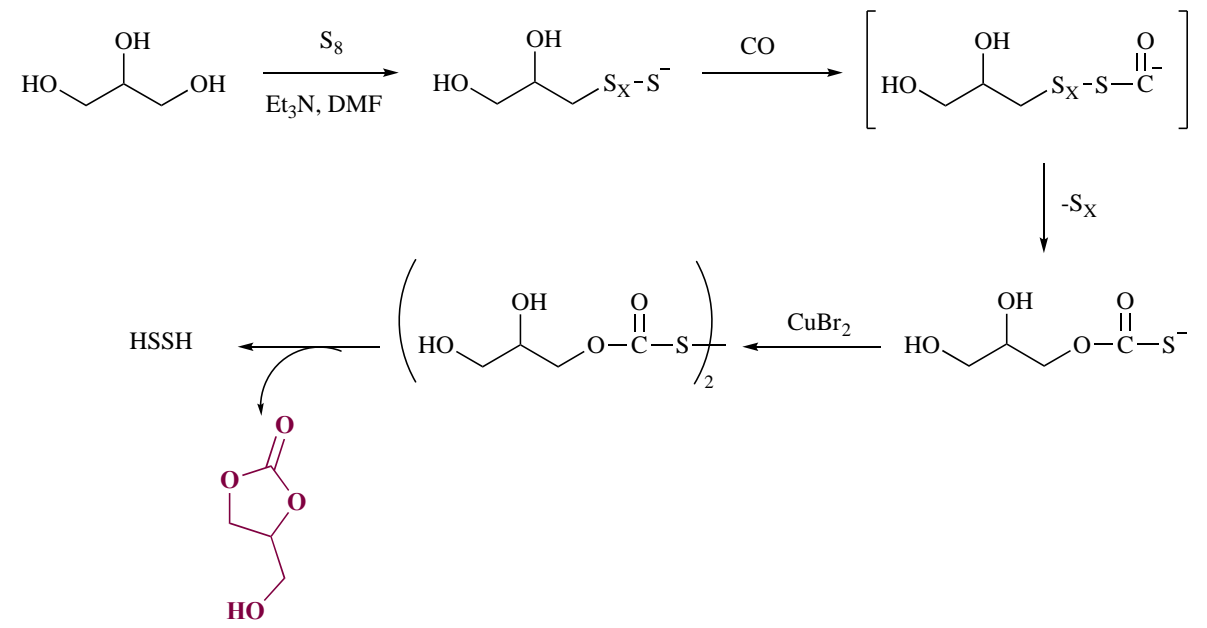

Scheme 7. Proposed mechanism for the sulfur-assisted oxidative carbonylation of GC.

Homogeneous catalysis system exhibits high-efficiency catalytic activity for this reaction route. However, due to the difficulty in separating the homogeneous catalyst from the reaction system, researchers are encouraged to search for more efficient heterogeneous catalysts.

Guang et al. [58] developed highly efficient homogeneous catalytic systems $\mathrm{PdCl}_{2}$ (phen)/KI and $\mathrm{PdCl}_{2}$ (phen)/CuI. Then, they explored a composite solid catalyst $\mathrm{PdCl}_{2}(\mathrm{phen}) \mathrm{xY}$ that used $\mathrm{CuI}$ and $\mathrm{KI}$ dual co-catalyst, with $\mathrm{N}, \mathrm{N}$-dimethylformamide as the solvent, at $1.6 \mathrm{MPaCO}, 0.8 \mathrm{MPaO}_{2}$, reacting at $120{ }^{\circ} \mathrm{C}$ for $3 \mathrm{~h}$. Finally, the high conversion rate of glycerol (95\%) and the high selectivity of GC $(98 \%)$ were realized. This composite catalyst was recycled five times without significant deactivation, $\mathrm{PdCl}_{2}$ (phen)xY, which opens the door to the study of heterogeneous catalytic systems.

\subsection{The Future of CO Oxidative Carbonylation Route}

All things considered, the above-mentioned experimental exploration provide a worthy point of view for future research on the oxidative carbonylation of glycerol to synthesize GC.

In summary, in the reaction process of this route, the most studied catalyst is the metal palladium catalyst, and, among them, the $\mathrm{PdCl}_{2}$ (phen)-KI catalyst system had the best catalytic effect $[59,60]$. The advantage of this synthetic route is that GC can be generated under relatively mild conditions, the product is easy to separate, the selectivity of the product is high, and the yield is high. However, as CO has certain toxicity and explosiveness, its industrial application is restricted. 


\section{3. $\mathrm{CO}_{2}$ Direct Carbonylation Route}

Also known as the $\mathrm{CO}_{2}$ conversion method, it refers to the direct reaction of $\mathrm{CO}_{2}$ and glycerol under certain conditions to produce GC.

As we all know, carbon dioxide is the main greenhouse gas, which is cheap and easy to obtain and non-toxic, while glycerol is a large by-product of the biodiesel industry. If the two are combined to synthesize high value-added chemicals, it will turn double waste into "treasure", has extremely high environmental value. In addition, the atomic utilization rate of the reaction can reach $87 \%$ [61], and the only by-product of the reaction is water, which shows that the reaction system is highly compatible with the concept of atomic economy and green chemistry.

The biggest problem with this route is that it is difficult to break the carbon-oxygen double bond in the $\mathrm{CO}_{2}$ molecule, which makes the chemical properties of $\mathrm{CO}_{2}$ highly stable and difficult to activate.

The choice of suitable combinations of catalyst and dehydration agent is crucial to achieving feasible yields in the synthesis of GC from glycerol and carbon dioxide. Usually, quiet harsh conditions are necessary with temperatures ranging from $120^{\circ} \mathrm{C}$ to $180^{\circ} \mathrm{C}$ and pressures varying from 30 bar to 150 bar [62]. Nevertheless, the current research shows that the glycerol conversion rate and GC yield of this route are not high, and the production cost is relatively high.

In order to solve the dehydration problem of the reaction, it was attempted the direct synthesis of GC with glycerol and carbon dioxide under the combined action of 1,8-diazabicycloundec-7-ene $/ \mathrm{CH}_{2} \mathrm{Br}_{2}$ [63]. This method used mild reaction conditions $\left(70{ }^{\circ} \mathrm{C}, 1 \mathrm{MPa}\right)$ and high yield of GC was obtained $(86 \%)$. However, $\mathrm{CH}_{2} \mathrm{Br}_{2}$ is toxic and expensive, which hinders the industrial application of this method.

It was reported that the yield of GC could be enhanced when acetonitrile was used as solvent and dehydration reagent in the carbonylation of glycerol and $\mathrm{CO}_{2}$. Such as, Podila et al. [64] showed that dibutyltin oxides also catalyze the synthesis of GC, resulting in yields of $7 \%$ in presence of acetonitrile. Additionally, in the presence of acetonitrile, $\mathrm{La}_{2} \mathrm{O}_{3}$ in combination with $\mathrm{ZnO}$ or $\mathrm{Cu}$ resulted in yields of up to $15 \%$ as reported from other research groups [65-67].

Although the improved yield was obtained using acetonitrile as the dehydration agent [68], acetonitrile is easily hydrolyzed to acetic acid, which could etherify with glycerol to decrease the yield of GC. The dehydration agent is important for the carbonylation of alcohols with $\mathrm{CO}_{2}$. 2-Cyanopyridine was also reported to be an effective dehydration agent [69-71]. For example, Liu et al. [72] found it to be effective for the carbonylation of glycerol with $\mathrm{CO}_{2}$ directly catalyzed by the $\mathrm{CeO}_{2}$ catalyst. Additionally, as reported by Su et al. [73], it was shown that if 2-cyanopyridine is used as dehydration agent and promoter, a GC yield of $18.7 \%$ was obtained without any further additives. Recently, Qiao Zhang et al. [74] described the application of $\mathrm{CaC}_{2}$ as a dehydrating agent for the direct synthesis of carbamates from amines, $\mathrm{CO}_{2}$, and $\mathrm{MeOH}$. Based on the use of $\mathrm{CaC}_{2}$, GC was successfully and directly synthesized from glycerol and $\mathrm{CO}_{2}$ under zinc catalysis and $\mathrm{N}$-donor ligand, in $92 \%$ yield. $\mathrm{CaC}_{2}$ itself is also a sustainable chemical and promotes the transformation of $\mathrm{CO}_{2}$ into valuable products.

With the aim of developing a green methodology, McGregor et al., for the first time, demonstrated the catalytic activities of untreated biochar and biochar ash, catalytic material that can readily be produced from low-value biomass residues, in the synthesis of GC from the reaction of glycerol, acetonitrile, and $\mathrm{CO}_{2}$ [75].

In a later study, the same authors provide novel insights into the behavior of dehydrating agents during the conversion of glycerol in the presence of carbon dioxide and a catalyst [76]. Particularly, they observed that conducting the reaction in the presence of adiponitrile resulted in a five-fold increase in GC yield when compared to acetonitrile, which is currently the most applied dehydrating agent.

In a very recent paper, $\mathrm{Hu}$ et al. [77] prepared a cobalt-based zeolitic imidazolate framework-67 (ZIF-67) as a catalyst for the carboxylation of glycerol in the presence of 
acetonitrile. The conversion, yield, and selectivity achieved with ZIF-67 were 32, 29, and $92 \%$, respectively, conducting the reaction at $210{ }^{\circ} \mathrm{C}$ for $12 \mathrm{~h}$. ZIF- 67 exhibited high crystallinity, a high specific surface area, good thermal stability as well as numerous Lewis basic sites, indicating its high catalytic activity.

In recent years, photocatalysis is becoming a hot field as introducing light into the thermally driven reaction system can improve the catalytic performance. To this aim, He et al. [78] prepared a series of $x_{2} a_{2} \mathrm{O}_{2} \mathrm{CO}_{3}-\mathrm{ZnO}$ catalysts, which were used for the photothermal transformation of glycerol and $\mathrm{CO}_{2}$ into GC. The photo-thermal synergism as well as the cooperation between $\mathrm{ZnO}$ and $\mathrm{La}_{2} \mathrm{O}_{2} \mathrm{CO}_{3}$ contributed to its catalytic performance, thus achieving a glycerol conversion of $6.9 \%$ under the reaction conditions of $150{ }^{\circ} \mathrm{C}$, $5.5 \mathrm{MPa} \mathrm{CO}_{2}$, and $20 \mathrm{mmol} \mathrm{g}^{-1}$ with a reaction time of $6 \mathrm{~h}$ when $20 \% \mathrm{La}_{2} \mathrm{O}_{2} \mathrm{CO}_{3}-\mathrm{ZnO}$ was used as the catalyst.

\subsection{The Future of $\mathrm{CO}_{2}$ Direct Carbonylation Route}

Although many researchers have worked on this route, experiments have proved that the direct reaction between glycerol and $\mathrm{CO}_{2}$ is extremely difficult. This reaction is thermodynamically limited from the production of water during the process; therefore, in order to remove water and to shift the equilibrium towards GC, the use of suitable dehydrating agents has been proposed over the years. Nevertheless, most of the reagents employed to remove water also result in formation of other by-products.

In many experimental examples, the following similar difficulties and problems are encountered: the conversion of glycerol is too low, the carbon dioxide reaction activity is reduced, the reaction needs to be carried out under high pressure conditions, the dehydrating agents are not effective.

Therefore, even if the reaction itself is extremely attractive and important, its application is still very limited. Due to the limitation of thermodynamics, it is impossible to promote the reaction between glycerol and $\mathrm{CO}_{2}$ simply by developing a new high-efficiency catalyst. Moreover, the method of adding dehydrating agents to move the reaction to the right has very limited effect. In short, for the current research on this reaction system, the development of a more effective reaction system will be the main way to solve the problem.

\section{Transesterification Route}

In recent years, the transesterification of glycerol and organic carbonates to synthesize GC has attracted attention. The organic carbonates raw materials used are mainly ethylene carbonate (EC), propylene carbonate (PC), dimethyl carbonate (DMC) and diethyl carbonate (DEC), while the catalysts are mainly inorganic or basic compounds, and lipase catalyst. In the alkaline catalytic environment, during the transesterification reaction, an excess of carbonate is generally added as both a reactant and a solvent, including the most widely used EC and DMC [17]. Figure 2 above depicts the main process of synthesizing GC through the transesterification reaction of EC or DMC with glycerol.

GC intermediates will be generated during the reaction, and the by-products of the reaction will be ethylene glycol (EG) or methanol, depending on the type of reactant carbonate. Li and Wang [61] studied the main differences between using EC and DMC as reactants and found that when $\mathrm{EC}$ is used as the reactant, the reaction equilibrium constant decreases with increasing temperature, while when DMC is used as the reactant, it is in contrast. For example, when using $\mathrm{Al} / \mathrm{Ca}$ mixed oxide as the catalyst, the temperature adopted in the reaction between EG and glycerol is $35^{\circ} \mathrm{C}$ [79], while to achieve the same GC conversion and selectivity, the temperature to be used in the reaction between DMC and glycerol should be higher than $80^{\circ} \mathrm{C}$ [80]. In this way, it seems easier and more energy-efficient to synthesize GC by the reaction of EG and glycerol.

However, the separation process of the product should also be considered. From the physical properties of the compound, it is known that the boiling points of $\mathrm{EC}\left(261^{\circ} \mathrm{C}\right)$ and EG $\left(197^{\circ} \mathrm{C}\right)$ are higher than the boiling points of $\mathrm{DMC}\left(90^{\circ} \mathrm{C}\right)$ and methanol $\left(64.5^{\circ} \mathrm{C}\right)$. The separation of EC and EG requires more energy input. Therefore, from the perspective 
of energy saving, the advantages and disadvantages of the two reactions can offset each other [81].

\subsection{Catalyst-Mediated Transesterification of EC with Glycerol}

Ethylene carbonate is the simplest substance containing ODO groups, which can provide carbonate for the transesterification reaction. The reaction pathway is divided into the following two steps: the first step is to synthesize EC with titanium dioxide and ethylene oxide; the second step is through the transesterification of EC with glycerol to synthesize GC [82]. With EC as the reactant, the catalysts currently used in research include $\mathrm{CaO}$, $\mathrm{Al} / \mathrm{Ca} / \mathrm{Mg}$ mixed oxides and hydrotalcite-like compounds, basic resins and molecular sieves, and also ionic liquids. The conversion rate after synthesis of GC is generally between $85-100 \%$, the selectivity of GC is between $84-99 \%$ [82].

Climent et al. [81] selected hydrotalcite mixed metal oxides ( $\mathrm{Al} / \mathrm{Mg}$ and $\mathrm{Al} / \mathrm{Li})$ and alkaline oxides $(\mathrm{MgO}$ and $\mathrm{CaO})$ as catalysts. The amount of catalyst was $0.5 \%$, the reaction temperature was $35{ }^{\circ} \mathrm{C}$, and finally a glycerol conversion of $98 \%$ was reached. They also showed that the strong alkaline $\mathrm{Al} / \mathrm{Ca}$-mixed oxide (AlCaMO) had the best catalytic activity. In the same year, Cho et al. [82] used ionic liquid as the catalyst, which was immobilized on the mesoporous material MCM41 (Mobil Composition of Matter No. 41, framework). The study showed that RNX-MCM41 with long alkyl chain had higher catalytic performance and its activity remained basically unchanged after it was used 3 times. Nevertheless, the method of synthesizing GC from glycerol and EC has the problem of not easily available raw materials, and the price is high. The by-product glycol produced in this reaction has a high boiling point making it difficult to separate from the product.

\subsection{Catalyst-Mediated Transesterification of DMC with Glycerol}

DMC is an environmentally friendly green chemical product, approved by European Union as a non-toxic substance that has become the most popular transesterification raw material in recent years. DMC is a solvent with a higher evaporation temperature and a faster evaporation rate. It has excellent solubility, can be used as a reactant and a solvent in the reaction system at the same time, no additional solvent is required. Not only does its reactivity meet the industry, but also its synthetic route is green and pollution-free $[83,84]$. However, the transesterification reaction of DMC with glycerol to afford GC is slow; hence, the catalyst plays a vital role in faster and selective production of GC. For this purpose, in recent years, the investigation of the reaction system of glycerol and DMC to synthesize GC, led to the search of different catalysts to be used in this reaction including alkali and alkaline-earth metal catalysts, mixed oxide catalysts, biological enzyme catalysts and ionic liquid catalysts [85-90].

\subsubsection{Alkali Metal Catalysts}

Gmehling et al. [85] used the basic catalyst $\mathrm{K}_{2} \mathrm{CO}_{3}$. The reaction can be carried out quantitatively and the selectivity is as high as $97 \%$, but $\mathrm{K}_{2} \mathrm{CO}_{3}$ is easily soluble in the reaction mixture, which makes the product GC difficult to be obtained. For separation, expensive ion exchange resins are currently used to separate products, which makes the process not economical. Sandesh et al. [86] investigated the performance of catalysts prepared by KF dispersed on different supports, and the results showed that $\gamma-\mathrm{Al}_{2} \mathrm{O}_{3}$ had the best catalytic performance when used as the support. When the reaction temperature was $75{ }^{\circ} \mathrm{C}$, the GC yield reached $95.8 \%$, and the activity did not change significantly after three cycles of use. The catalytic activity was only reduced by $3 \%$. The disadvantage is that the reaction uses toxic DMF as the reaction solvent. $\mathrm{NaOH} / \gamma-\mathrm{Al}_{2} \mathrm{O}_{3}$ with $80 \% \mathrm{NaOH}$ mass fraction was also considered to be an effective catalyst for the transesterification of DMC and glycerol. After reacting at $78{ }^{\circ} \mathrm{C}$ for $1 \mathrm{~h}$, the conversion and selectivity reached $98 \%$ and $99 \%$, respectively [87].

Ramesh et al. [88] found that at room temperature, nano- $\mathrm{NaAlO}_{2}$ can catalyze the synthesis of GC and the afforded yield was $83 \%$. Subsequently, the same authors [89] loaded 
$10 \%$ of $\mathrm{NaAlO}_{2}$ on magnesia-aluminum hydrotalcite, which not only greatly enhanced the alkalinity, but also improved the stability of $\mathrm{NaAlO}_{2}$. When the reaction temperature reached $90{ }^{\circ} \mathrm{C}$, the yield and selectivity could reach $92 \%$ and $100 \%$, respectively, and there was no significant decrease in activity after the catalyst is recycled three times.

\subsubsection{Alkaline-Earth Metal Oxide Catalysts}

$\mathrm{NaAlO}_{2}$ was shown to be one of the most promising catalysts because it is economical and easy to synthesize [90].

Nevertheless, it is still of great concern and challenging to improve the activity of a $\mathrm{NaAlO}_{2}$ catalyst to achieve as high a GC yield as possible. In an article in press, Chotchuang et al. [91] report the modification of the $\mathrm{NaAlO}_{2}$ catalyst with $\mathrm{CaO}$ as a promoter in order to increase its basicity. $\mathrm{CaO}$ was chosen because it is the most suitable basic oxide among the alkaline earth metal oxides because it is cheap and easy to obtain, and the post-treatment does not cause environmental problems. The results showed that sodium aluminate modified with $\mathrm{CaO}$ at $5 \%$ by weight $\left(\mathrm{NA}_{5} \mathrm{Ca}\right.$ ) and using $45 \%$ glycerol template by weight of $\mathrm{NA}_{5} \mathrm{Ca}\left(\mathrm{NA}_{5} \mathrm{Ca}-45 \mathrm{G}\right)$ produced the most active catalyst among those prepared. By varying the operational parameters using a catalyst content of $30 \%$ by weight of glycerol reactant, a glycerol:DMC molar ratio of 1:4, a reaction temperature of $70{ }^{\circ} \mathrm{C}$, and a reaction time of $3 \mathrm{~h}$, the maximum GC yield of $\mathrm{NA}_{5} \mathrm{Ca}-45 \mathrm{G}$ was $90.5 \%$ with $100 \%$ selectivity. However, after the first use of $\mathrm{CaO}$, the catalytic activity is significantly reduced and cannot be recycled. According to the further study of Li and Wang [92], the inactivation of $\mathrm{CaO}$ is mainly due to the conversion of $\mathrm{CaO}$ to $\mathrm{Ca}_{\mathrm{x}}(\mathrm{OH})_{\mathrm{y}}\left(\mathrm{CO}_{3}\right)_{\mathrm{z}}$ during the reaction. To restore the catalyst activity, the recovered catalyst must be calcined, which is a very complicated and tedious operation process that also requires a lot of energy consumption. Of course, the mechanism of $\mathrm{CaO}$ inactivation during the reaction has many possible situations, and further research is needed.

In order to overcome the technical obstacles caused by catalyst deactivation, $\mathrm{Li}$ and Wang [93] developed a process in which $\mathrm{CaO}$ was also used as a catalyst, and the reaction product methanol was continuously removed through the azeotropic distillation, thereby shifting the balance of the transesterification reaction to the right. When the DMC:glycerol molar ratio was $1: 1$, the azeotropic distillation termination temperature was $85^{\circ} \mathrm{C}$, and the yield was as high as $98 \%$. More importantly, after recycling the inactivated $\mathrm{CaO}$, the yield remained at a high level. The disadvantage of the process is the use of toxic chemicals, such as a large amount of benzene, therefore this process industry needs further research to achieve green synthesis.

\subsubsection{Mixed Oxide Catalyst}

Oprescu et al. [94] reported that hydrotalcite catalyzed the reaction between glycerol and DMC, and the GC yield was only $23 \%$. The catalytic performance of $\mathrm{Al} / \mathrm{Mg}, \mathrm{Al} / \mathrm{Li}$, $\mathrm{Al} / \mathrm{Ca}$ mixed oxide hydrotalcite (c-HTs) was obviously improved after calcination. At present, it has been extensively studied and discussed to further improve the catalytic performance of c-HTs through rehydration or doping with transition metals. Both increase the total alkalinity of the catalyst, thereby improving the catalytic performance. Compared with c-HTs, rehydration catalyst can increase the catalytic performance by 25\% [95].

Granados-Reyes et al. [96] found that mayenite was more stable than a pure $\mathrm{CaO}$ catalyst. This is because the mayenite around $\mathrm{CaO}$ prevents the contact of $\mathrm{CaO}$ with air to a certain extent. In addition, long-term calcination or calcination in an inert atmosphere can easily generate mayenite $\mathrm{Ca}(\mathrm{Al}) \mathrm{O}_{\mathrm{x}}$ with low crystallinity and increase its strong alkalinity.

Song et al. [97] used the impregnation method to prepare Li-ZnO catalysts, and found that the greater the Li loading, the more basic the catalyst. Under the optimal conditions, the glycerol conversion rate reached $97.4 \%$, the GC yield reached $95.84 \%$, and the activity did not change significantly after three cycles of use.

Algoufi et al. [98] studied the $\mathrm{CaO}-\mathrm{MgO}$ catalyst prepared by dolomite, the alkali strength was $15<\mathrm{H}<18$, the glycerol conversion reached $97 \%$, and the GC yield reached 
94\%. Subsequently, using Sr-Al mixed oxide as a catalyst, it was obtained a $99.4 \%$ glycerol conversion and 100\% GC yield, and the catalyst could be recycled five times [99].

Ali and Kaur [100] prepared a $20-\mathrm{Li} / \mathrm{ZrO}_{2}-700$ catalyst by the wet impregnation method and found that it was an effective catalyst for the transesterification of glycerol with DMC yielding GC as an exclusive product. The process was also simple and cost efficient because the catalyst could be recovered and recycled with only a gradual decrease in its catalytic activity after each run.

In a very recent study, Arora et al. [101] explored the catalytic activity of lithium impregnated on MCM-41; the results showed that $99 \%$ glycerol conversion and $93.14 \%$ GC yield was attained with a DMC:glycerol molar ratio of three and using a catalyst dosage of $4 \mathrm{wt} \%$ (relative to glycerol mass) and conducting the reaction at $90{ }^{\circ} \mathrm{C}$ for $3 \mathrm{~h}$. The authors also calculated the E-factor and process mass intensity values of GC synthesis further demonstrating the less waste generation during the process.

Jiang et al. [102] prepared an acidic-basic bifunctional magnetic mesoporous $\mathrm{CoFe}_{2} \mathrm{O}_{4} \times(\mathrm{CaO}-\mathrm{ZnO})$ solid base catalyst for the glycerol transesterification (Scheme 8). Basic sites were beneficial to the activation of glycerol to glycerol oxygen anion to increase glycerol conversion $(97.7 \%)$ and acidic sites were beneficial to carbonyl activation of DMC to increase GC selectivity (99.2\%). As the solid base catalyst was easily recovered under magnetic action, the process is in line with the concept of sustainable chemistry.
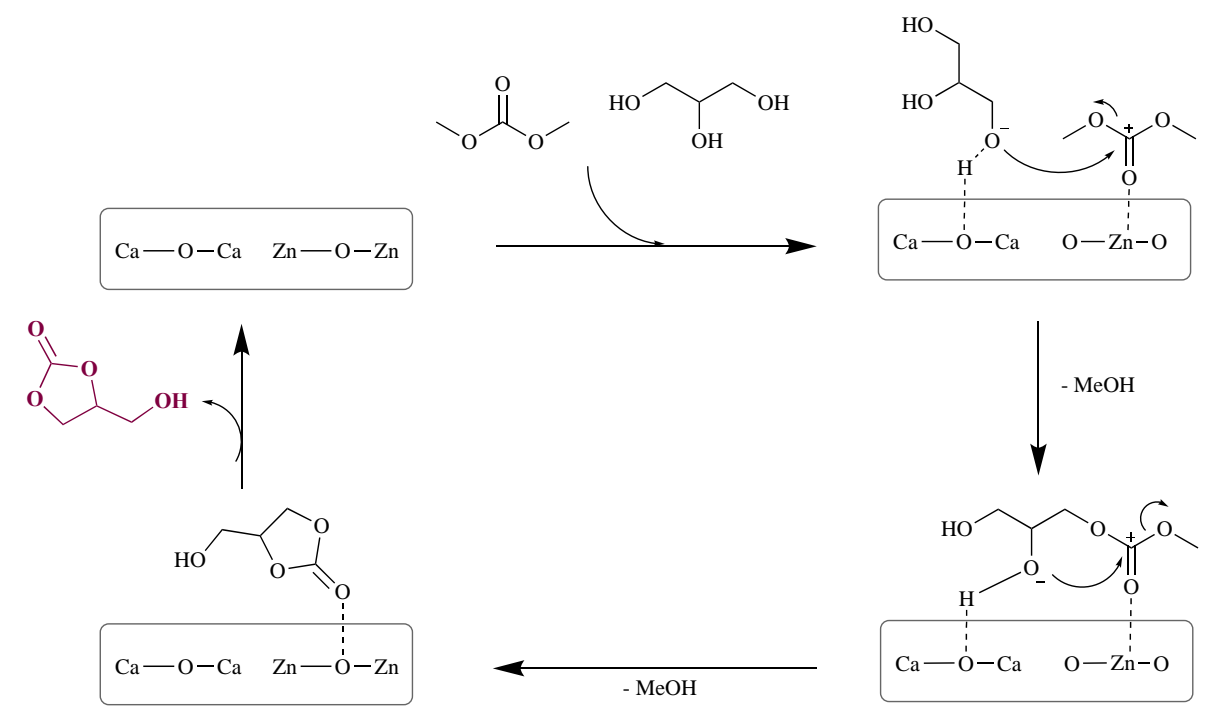

Scheme 8. $\mathrm{CaO}-\mathrm{ZnO}$ solid base catalyst for the glycerol transesterification.

Recently, Praikaew et al. [103] used natural waste egg shell-derived CaO catalyst as raw material. A glycerol conversion and GC yield of $93 \%$ and $91 \%$, respectively, could be achieved within 15 min of reaction time. Additionally, a series of Fe-La oxide catalysts with different molar compositions were further synthesized [104] and studied for the continuous synthesis of GC by transesterification of glycerol with DMC. The catalyst with a molar ratio of $1: 1$ calcined at $550{ }^{\circ} \mathrm{C}$ exhibited superior activity yielding $71 \%$ of GC. Of note is the unprecedent stability of the catalysts for over $100 \mathrm{~h}$ during on-stream analysis.

With the aim of exploring novel catalysts, in 2020, Arora et al. [105] for the first time prepared a series of potassium incorporated three-dimensional mesoporous silica material (K/TUD-1) to be tested for the one-pot synthesis of GC through transesterification of glycerol with DMC. The catalyst showed a good basicity that favored the reaction. The optimized reaction conditions were the following: catalyst dose of $6 \mathrm{wt} \%, \mathrm{DMC} /$ glycerol molar ratio of $5: 1$, at $90{ }^{\circ} \mathrm{C}$ for $2.5 \mathrm{~h}$ enabling a GC yield of about $91.50 \%$. 


\subsubsection{Bio-Catalyst}

Enzyme catalysis refers to the use of biological macromolecules produced by biological cells to catalyze the conversion of glycerol into GC. This type of catalyst has the advantages of high conversion rate, mild reaction conditions, non-toxic residue and can completely solve the problem of catalyst residue. Therefore, enzymatic reactions have attracted more and more attention in recent years [106].

Currently, CAL (Candida Antarctica Lipase) immobilized on polyacrylic resin is one of the best lipase catalysts for catalyzing the transesterification reaction of DMC and glycerol. However, due to the poor solubility of the reaction raw materials, a hydrophilic glycerol film will be formed on the surface of the lipase, thereby inhibiting the enzyme's catalytic effect. To solve this problem, Lee et al. [107] used a solid silica support to adsorb glycerol, forming an active interface between DMC and glycerol. The reaction was conducted for $48 \mathrm{~h}$ at $70{ }^{\circ} \mathrm{C}$ giving a conversion higher than $90 \%$, and the selectivity reached $100 \%$. However, the authors pointed out that the catalyst has poor repeatability, and the lipase activity dropped by more than $50 \%$ after five cycles. Waghmare et al. [108] used the enzyme Novozym 435 to study its effect of on the yield of GC under ultrasonic irradiation. The experiment found that when the molar ratio of glycerol to DMC was 3:1, adding $13 \%$ enzyme and reacting in tert-butanol at $60{ }^{\circ} \mathrm{C}$ for $4 \mathrm{~h}$, the conversion rate of glycerol was as high as $99.75 \%$.

Du et al. [109] fixed CALB (lipase B of Candida antarctica) on magnetic organosilicon nanoflowers to obtain biocatalyst CALB nanoflowers and performed the reaction for $24 \mathrm{~h}$ at $50{ }^{\circ} \mathrm{C}$ using an alcohol/ester ratio of $1 / 20$. The glycerol conversion rate reached $94.2 \%$, GC yield reached $88.7 \%$ and the biocatalyst can still maintain more than $70 \%$ of its activity after being used 7 times.

\subsubsection{Ionic Liquid Catalyst (ILs)}

In recent years, many researchers have explored ILs to catalyze the transesterification reaction between DMC and glycerol [110]. Wang et al. [111] synthesized a series of IL catalysts for transesterification to synthesize GC. The results showed that [TMG][TFE] had the best effect among the synthesized ionic liquids, and the conversion of glycerol reached $91.8 \%$ at $80{ }^{\circ} \mathrm{C}$ for $30 \mathrm{~min}$ while the selectivity of GC was $95.5 \%$.

In recent years, it was found that some amines, especially 1,4-diazabicyclo [2.2.2] octane (DABCO), can be used as catalysts in this reaction system, but there is still a problem of difficulty in catalyst recovery [112]. So, they introduced these polyamines into the chloromethyl resin during the synthetic process. The chlorine atom in the chloromethyl resin is easily replaced by the $N$ atom of the tertiary amine and fixed on the polymer carrier to obtain a basic catalyst. This catalyst has high esterification activity and can be recycled five times.

Recent studies have shown that basic ILs catalysts are more active than neutral or acid ILs. For example, using [BMIM][IM] as the catalyst, the amount of catalyst was $10 \%$, the reaction was carried out at $70{ }^{\circ} \mathrm{C}$ for $1.5 \mathrm{~h}$, the glycerol conversion was $98.4 \%$ and the GC selectivity was $100 \%$ [80]. The feasibility of the process is mainly due to the $[\mathrm{IM}]$ anion involved in strong hydrogen bonding interaction with the hydroxyl groups of glycerol, resulting in the facile formation of the corresponding hydroxide anion and nucleophilic attack on the carbonyl group of DMC, as also demonstrated in another study by Yi et al. [113].

An efficient approach was developed by Martinez-Palou et al. [114] using polyIL catalysts derived from 1-vinylimidazole and containing the imidazolate anion. The polymeric catalysts, evaluated at 5 and 10 mol.\%, showed more than $90 \%$ reaction conversion. An important advantage is that the polymeric catalysts were separated and recycled in more than two successive reaction cycles without significant catalytic activity loss (Scheme 9). 


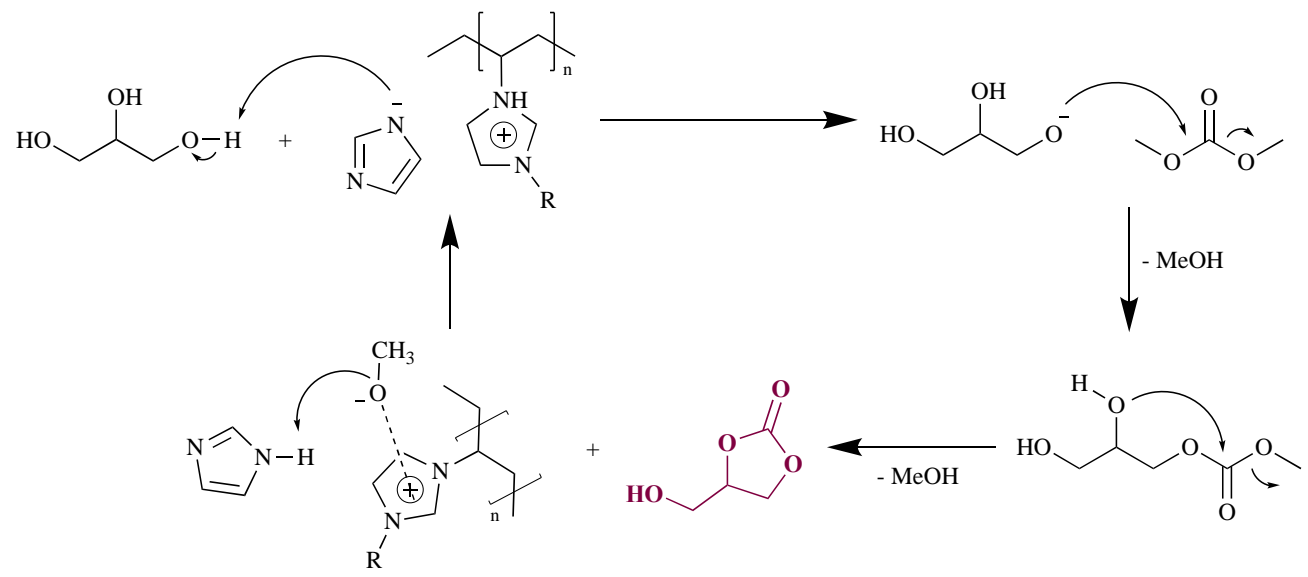

Scheme 9. Proposed reaction mechanism to prepare GC catalyzed by polyILs.

However, the price of ILs is significantly higher than that of heterogeneous catalysts, and the separation cost of ILs is expensive, which makes the scale of application of ILs limited to the laboratory stage currently.

\subsection{The Future of the Transesterification Route}

In view of the advantages and disadvantages of various types of catalysts, the best catalyst can be selected according to specific needs to suit the operating environment and economic conditions. For example, when considering economic benefits and production efficiency, you can choose the cheap alkaline-earth metal $\mathrm{CaO}$, without considering its shortcomings of easy inactivation; when you need to obtain high purity and high valueadded chemicals, you can choose high activity, stable but expensive catalysts, such as ILs, etc. At the same time, from the process point of view, the reactants are either not easy to obtain, or the synthesis cost is high, the process is complicated, and the reaction products are difficult to separate. Therefore, for the development of GC green synthesis, it is particularly important to seek a more optimized process for the reaction system.

\section{Features of the Four Synthetic Routes to GC}

Mainly four synthetic routes have been extensively studied (Table 2. Each route to GC has a different catalytic system mainly divided into different categories, namely the following: metal salt catalysts, metal oxide catalysts, hydrotalcite catalysts, ionic liquid catalysts, and enzyme catalysts. Their advantages and disadvantages are shown in Table below.

Table 2. Comparison of the main synthetic routes to GC.

\begin{tabular}{|c|c|c|c|c|}
\hline Synthetic Route & Material & $\begin{array}{l}\text { Representative } \\
\text { Catalysts }\end{array}$ & Advantage & Disadvantage \\
\hline Phosgene route & Phosgene & - & Low reaction temperature, high yield & Raw materials are highly toxic \\
\hline Urea route & Urea & $\begin{array}{l}\text { Hydrotalcite catalysts } \\
\text { Ionic liquid catalysts } \\
\text { Metal salt catalyst } \\
\text { Metal oxide catalyst } \\
\text { Metal oxide catalysts }\end{array}$ & $\begin{array}{c}\text { Easy to obtain raw materials, high } \\
\text { yield, high selectivity }\end{array}$ & $\begin{array}{l}\text { Generates } \mathrm{NH}_{3}, \text { requires } \\
\text { decompression conditions, and } \\
\text { requires high equipment }\end{array}$ \\
\hline Transesterification route & $\mathrm{EC} / \mathrm{DMC}$ & $\begin{array}{l}\text { Metal oxide catalysts } \\
\text { Metal salt catalyst } \\
\text { Hydrotalcite catalysts } \\
\text { Ionic liquid catalysts }\end{array}$ & $\begin{array}{l}\text { Mild reaction conditions and simple } \\
\text { operation }\end{array}$ & $\begin{array}{l}\text { The catalyst is easy to deactivate, } \\
\text { the economy is poor }\end{array}$ \\
\hline $\mathrm{CO} / \mathrm{CO}_{2}$ & $\begin{array}{c}\mathrm{CO}+\mathrm{O}_{2} \\
\mathrm{CO}_{2}\end{array}$ & $\begin{array}{l}\text { Metal salt catalyst } \\
\text { Metal oxide catalysts }\end{array}$ & $\begin{array}{l}\text { High yield and easy separation } \\
\text { Turn waste into treasure, } \\
\text { environmental protection, high } \\
\text { selectivity }\end{array}$ & $\begin{array}{c}\text { Raw materials are toxic, have } \\
\text { potential safety hazards } \\
\text { Low yield, high reaction } \\
\text { conditions }\end{array}$ \\
\hline
\end{tabular}




\section{Conclusions and Prospects for the Synthesis of GC}

This review presented the up-to-date trends of research on the synthesis of glycerol carbonate as a value-added product that addresses a real need in the marketplace for a functional, cost effective, renewable intermediate.

As an environmentally friendly compound, on the one hand, GC can be used as an organic synthesis intermediate with excellent properties and is widely used in various fields of the chemical industry. On the other hand, it can effectively alleviate the serious excess of biodiesel by-product glycerol. The development and application of GC synthesis technology is one of the important ways to realize the comprehensive utilization of glycerol with high value added and promote the sustainable development of the biodiesel industry. However, there are still many shortcomings among the existing routes to produce GC. A comparative study of the main synthetic routes to GC has been carried out considering industrial feasibility. As a result, transesterification of DMC with glycerol appears to be the most suitable route to GC industrial manufacturing. Nevertheless, in the future, whether it is research or industrialization, more attention and investment from academia and industry are urgently needed.

In terms of research, it is necessary to continue to develop high-performance catalysts with high catalytic activity and selectivity, recyclability, good stability, easy separation, and cost-effectiveness. In addition, various physical and chemical methods need to be performed to characterize the active sites of the catalyst, establish the structure-activity relationship between the structure and performance of the catalyst, and provide theoretical guidance for the design of new catalysts. The problems associated with homogeneous catalysts and biocatalyst can be resolved by heterogeneous catalysts which give out excellent reusability with easy product separation. Moreover, in order to up-grade the cost-effectiveness of the process, heterogeneous catalysts derived from waste materials should be preferably exploited.

In terms of industrialization, it is necessary to further optimize raw materials, reduce energy consumption, control reaction conditions, reduce waste emissions, simplify reaction steps, and reduce product costs. No less interesting is the focus on downstream industry applications of GC to expand market demand.

Author Contributions: Conceptualization, D.P.; data curation, D.P. and M.L.D.G.; writing—original draft preparation, D.P. and M.L.D.G.; writing-review and editing, D.P. and M.L.D.G.; supervision, M.L.D.G. All authors have read and agreed to the published version of the manuscript.

Funding: This research received no external funding.

Institutional Review Board Statement: Not applicable.

Informed Consent Statement: Not applicable.

Data Availability Statement: Not applicable.

Conflicts of Interest: The authors declare no conflict of interest.

\section{References}

1. Yalcin, S.; Konukman, A.E.S.; Midilli, A. A perspective on fossil fuel based flue gas emission reduction technologies. Greenh. Gases Sci. Technol. 2020, 10, 664-677. [CrossRef]

2. Konur, O. (Ed.) Biodiesel Fuels Based on Edible and Nonedible Feedstocks, Wastes, and Algae: Science, Technology, Health, and Environment, 1st ed.; CRC Press: Boca Raton, FL, USA, 2021. [CrossRef]

3. Habib, M.S.; Asghar, O.; Hussain, A.; Imran, M.; Mughal, M.P.; Sarkar, B. A robust possibilistic programming approach toward animal fat-based biodiesel supply chain network design under uncertain environment. J. Clean. Prod. 2021, 278, 122403. [CrossRef]

4. Kumar, A.; Tirkey, J.V.; Shukla, S.K. Comparative energy and economic analysis of different vegetable oil plants for biodiesel production in India. Renew. Energy 2021, 169, 266-282. [CrossRef]

5. Pasha, M.K.; Dai, L.; Liu, D.; Guo, M.; Du, W. An overview to process design, simulation and sustainability evaluation of biodiesel production. Biotechnol. Biofuels 2021, 14, 129. [CrossRef] [PubMed]

6. Global Biofuel Production 2000-2020. N. Sönnichsen. 2021. Available online: https://www.statista.com/statistics/274163/globalbiofuel-production-in-oil-equivalent/\#statisticContainer (accessed on 3 December 2021). 
7. Quispe, C.A.G.; Coronado, C.J.R.; Carvalho, J.A., Jr. Glycerol: Production, consumption, prices, characterization and new trends in combustion. Renew. Sustain. Energy Rev. 2013, 27, 475-493. [CrossRef]

8. Ciriminna, R.; Della Pina, C.; Rossi, M.; Pagliaro, M. Understanding the glycerol market. Eur. J. Lipid Sci. Technol. 2014, 116, 1432-1439. [CrossRef]

9. Kumar, L.R.; Yellapu, S.K.; Tyagi, R.D.; Zhang, X. A review on variation in crude glycerol composition, bio-valorization of crude and purified glycerol as carbon source for lipid production. Bioresour. Technol. 2019, 293, 122-155. [CrossRef]

10. He, Q.; McNutt, J.; Yang, J. Utilization of the residual glycerol from biodiesel production for renewable energy generation. Renew. Sustain. Energy Rev. 2017, 71, 63-76. [CrossRef]

11. Ono, Y. Dimethyl carbonate for environmentally benign reactions. Catal. Today 1997, 35, 15-25. [CrossRef]

12. Sonnati, M.O.; Amigoni, S.; de Givenchy, E.P.T.; Darmanin, T.; Choulet, O.; Guittard, F. Glycerol carbonate as a versatile building block for tomorrow: Synthesis, reactivity, properties and applications. Green Chem. 2012, 15, 283-306. [CrossRef]

13. Nomanbhay, S.; Ong, M.Y.; Chew, K.W.; Show, P.-L.; Lam, M.K.; Chen, W.-H. Organic Carbonate Production Utilizing Crude Glycerol Derived as By-Product of Biodiesel Production: A Review. Energies 2020, 13, 1483. [CrossRef]

14. Magniont, C.; Escadeillas, G.; Oms-Multon, C.; De Caro, P. The benefits of incorporating glycerol carbonate into an innovative pozzolanic matrix. Cem. Concr. Res. 2010, 40, 1072-1080. [CrossRef]

15. Hülsey, M.J.; Yang, H.Y.; Yan, N. Sustainable Routes for the Synthesis of Renewable Heteroatom-Containing Chemicals. ACS Sustain. Chem. Eng. 2018, 6, 5694-5707. [CrossRef]

16. Ochoa-Gómez, J.R.; Gómez-Jiménez-Aberasturi, O.; Ramírez-López, C.; Belsué, M. A Brief Review on Industrial Alternatives for the Manufacturing of Glycerol Carbonate, a Green Chemical. Org. Process. Res. Dev. 2012, 16, 389-399. [CrossRef]

17. De Caro, P.; Bandres, M.; Urrutigoïty, M.; Cecutti, C.; Thiebaud-Roux, S. Recent Progress in Synthesis of Glycerol Carbonate and Evaluation of Its Plasticizing Properties. Front. Chem. 2019, 7, 308. [CrossRef] [PubMed]

18. Strain, F. Carbonate-Haloformate of Glycerol and Method of Producing Same. U.S. Patent 2446145, 27 July 1948.

19. Dibenedetto, A.; Angelini, A. Chapter Two-Synthesis of Organic Carbonates. In Advances in Inorganic Chemistry; Aresta, M., van Eldik, R., Eds.; Academic Press: Amsterdam, The Netherlands, 2014; Volume 66, pp. 25-81. ISBN 9780124202214. [CrossRef]

20. Poliakoff, M.; Licence, P. Green chemistry. Nature 2007, 450, 810-812. [CrossRef]

21. Singh, G.; Pradhan, G.; Pradhan, S.; Sharma, Y.C. Transformation of Biodiesel waste Glycerol to Value added Glycerol Carbonate. Chem. Sci. Rev. Lett. 2020, 9, 1003-1013.

22. Meessen, J.H.; Petersen, H. Urea. In Ullmann's Encyclopedia of Industrial Chemistry; Wiley-VCH Verlag GmbH \& Co. KGaA: Weinheim, Germany, 2000.

23. Shukla, K.; Srivastava, V.C. Synthesis of organic carbonates from alcoholysis of urea: A review. Catal. Rev. 2017, 59, 1-43. [CrossRef]

24. Rubio-Marcos, F.; Calvino-Casilda, V.; Bañares, M.A.; Fernandez, J.F. Novel hierarchical $\mathrm{Co}_{3} \mathrm{O}_{4} / \mathrm{ZnO}$ mixtures by dry nanodispersion and their catalytic application in the carbonylation of glycerol. J. Catal. 2010, 275, 288-293. [CrossRef]

25. Calvino-Casilda, V.; Mul, G.; Fernández, J.; Rubio-Marcos, F.; Bañares, M.A. Monitoring the catalytic synthesis of glycerol carbonate by real-time attenuated total reflection FTIR spectroscopy. Appl. Catal. A Gen. 2011, 409-410, 106-112. [CrossRef]

26. Lopez-Sanchez, J.A.; Dimitratos, N.; Glanville, N.; Kesavan, L.; Hammond, C.; Edwards, J.K.; Carley, A.F.; Kiely, C.J.; Hutchings, G.J. Reactivity studies of Au-Pd supported nanoparticles for catalytic applications. Appl. Catal. A Gen. 2011, 391, 400-406. [CrossRef]

27. Zhang, H.; Li, H.; Wang, A.; Xu, C.; Yang, S. Progress of Catalytic Valorization of Bio-Glycerol with Urea into Glycerol Carbonate as a Monomer for Polymeric Materials Heng. Adv. Polym. Technol. 2020, 2020, 1-17. [CrossRef]

28. Park, J.-H.; Choi, J.S.; Woo, S.K.; Lee, S.D.; Cheong, M.; Kim, H.S.; Lee, H. Isolation and characterization of intermediate catalytic species in the Zn-catalyzed glycerolysis of urea. Appl. Catal. A Gen. 2012, 433-434, 35-40. [CrossRef]

29. Fujita, S.-I.; Yamanishi, Y.; Arai, M. Synthesis of glycerol carbonate from glycerol and urea using zinc-containing solid catalysts: A homogeneous reaction. J. Catal. 2013, 297, 137-141. [CrossRef]

30. Zuhaimi, N.A.S.; Indran, V.P.; Deraman, M.A.; Mudrikah, N.F.; Maniam, G.P.; Taufiq-Yap, Y.H.; Rahim, M.H.A. Reusable gypsum based catalyst for synthesis of glycerol carbonate from glycerol and urea. Appl. Catal. A Gen. 2015, 502, 312-319. [CrossRef]

31. Wang, D.; Zhang, X.; Liu, C.; Cheng, T. Synthesis of glycerol carbonate from glycerol and urea over lanthanum compounds. React. Kinet. Mech. Catal. 2015, 115, 597-609. [CrossRef]

32. Charate, S.; Shinde, S.; Kondawar, S.; Desai, U.; Wadgaonkar, P.; Rode, C. Role of preparation parameters of Cu-Zn mixed oxide catalyst in solvent free glycerol carbonylation with urea. J. Indian Chem. Soc. 2021, 98, 100090. [CrossRef]

33. Chen, J.; Wang, C.; Dong, B.; Leng, W.; Huang, J.; Ge, R.; Gao, Y. Ionic liquids as eco-friendly catalysts for converting glycerol and urea into high value-added glycerol carbonate. Chin. J. Catal. 2015, 36, 336-343. [CrossRef]

34. Di Gioia, M.L.; Barattucci, A.; Bonaccorsi, P.; Leggio, A.; Minuti, L.; Romio, E.; Temperini, A.; Siciliano, C. Deprotection/reprotection of the amino group in $\alpha$-amino acids and peptides. A one-pot procedure in [Bmim][BF4] ionic liquid. RSC Adv. 2014, 4, 2678-2686. [CrossRef]

35. Kim, D.-W.; Park, K.-A.; Kim, M.-J.; Kang, D.-H.; Yang, J.-G.; Park, D.-W. Synthesis of glycerol carbonate from urea and glycerol using polymer-supported metal containing ionic liquid catalysts. Appl. Catal. A Gen. 2014, 473, 31-40. [CrossRef] 
36. Kim, D.-W.; Kim, M.-J.; Roshith, K.; Kim, M.-I.; Kwak, J.-Y.; Park, D.-W. Comparative catalytic activity of supported ZnBr2containing ionic liquid catalysts for preparation of glycerol carbonate by glycerolysis of urea. Korean J. Chem. Eng. 2014, 31, 972-980. [CrossRef]

37. Kim, D.-W.; Park, D.-W. Organic-Inorganic Hybrids of Imidazole Complexes of Zinc (II) for Catalysts in the Glycerolysis of Urea. J. Nanosci. Nanotechnol. 2014, 14, 4632-4638. [CrossRef] [PubMed]

38. Jagadeeswaraiah, K.; Kumar, C.R.; Prasad, P.S.S.; Lingaiah, N. Incorporation of Zn2+ ions into the secondary structure of heteropoly tungstate: Catalytic efficiency for synthesis of glycerol carbonate from glycerol and urea. Catal. Sci. Technol. 2014, 4, 2969-2977. [CrossRef]

39. Jagadeeswaraiah, K.; Kumar, C.R.; Prasad, P.S.S.; Loridant, S.; Lingaiah, N. Synthesis of glycerol carbonate from glycerol and urea over tin-tungsten mixed oxide catalysts. Appl. Catal. A Gen. 2014, 469, 165-172. [CrossRef]

40. Kumar, C.R.; Jagadeeswaraiah, K.; Prasad, P.S.S.; Lingaiah, N. Samarium-exchanged Heteropoly Tungstate: An Efficient Solid Acid Catalyst for the Synthesis of Glycerol Carbonate from Glycerol and Benzylation of Anisole. ChemCatChem 2012, 4, $1360-1367$. [CrossRef]

41. Babu, M.S.; Srivani, A.; Parameswaram, G.; Veerabhadram, G.; Lingaiah, N. Understanding the Role of Tantalum in Heteropoly Tungstate Catalysts for the Synthesis of Glycerol Carbonate from Glycerol and Urea. Catal. Lett. 2015, 145, 1784-1791. [CrossRef]

42. Jagadeeswaraiah, K.; Kumar, C.R.; Rajashekar, A.; Srivani, A.; Lingaiah, N. The Role of Tungsten Oxide Species Supported on Titania Catalysts for the Synthesis of Glycerol Carbonate from Glycerol and Urea. Catal. Lett. 2016, 146, 692-700. [CrossRef]

43. Srikanth, A.; Viswanadham, B.; Kumar, V.P.; Anipindi, N.R.; Chary, K.V.R. Synthesis and characterization of Cs-exchanged heteropolyacid catalysts functionalized with Sn for carbonolysis of glycerol to glycerol carbonate. Appl. Petrochem. Res. 2015, 6, 145-153. [CrossRef]

44. Mallesham, B.; Rangaswamy, A.; Rao, B.G.; Rao, T.V.; Reddy, B.M. Solvent-Free Production of Glycerol Carbonate from Bioglycerol with Urea Over Nanostructured Promoted $\mathrm{SnO}_{2}$ Catalysts. Catal. Lett. 2020, 150, 3626-3641. [CrossRef]

45. Wang, L.; Ma, Y.; Wang, Y.; Liu, S.; Deng, Y. Efficient synthesis of glycerol carbonate from glycerol and urea with lanthanum oxide as a solid base catalyst. Catal. Commun. 2011, 12, 1458-1462. [CrossRef]

46. Lari, M.G.; de Moura, A.B.L.; Weimann, L.; Mitchell, S.; Mondelli, C.; Pérez-Ramírez, J. Design of a technical Mg-AI mixed oxide catalyst for the continuous manufacture of glycerol carbonate. J. Mat. Chem. A 2017, 5, 16200-16211. [CrossRef]

47. Zhang, P.; Liu, L.; Fan, M.; Dong, Y.; Jiang, P. The value-added utilization of glycerol for the synthesis of glycerol carbonate catalyzed with a novel porous ZnO catalyst. RSC Adv. 2016, 6, 76223-76230. [CrossRef]

48. Borysiewicz, M.A. ZnO as a Functional Material, a Review. Crystals 2019, 9, 505. [CrossRef]

49. Manjunathan, P.; Ravishankar, R.; Shanbhag, G.V. Novel bifunctional Zn-Sn composite oxide catalyst for the selective syn-thesis of glycerol carbonate by carbonylation of glycerol with urea. ChemCatChem 2016, 8, 631-639. [CrossRef]

50. Ahire, J.; Bhanage B., M. Solar energy-controlled shape selective synthesis of zinc oxide nanomaterials and its catalytic appli-cation in synthesis of glycerol carbonate. J. Solid State Chem. 2021, 295, 121927. [CrossRef]

51. Peng, J.-B.; Geng, H.-Q.; Wu, X.-F. The Chemistry of CO: Carbonylation. Chem 2018, 5, 526-552. [CrossRef]

52. Ozorio, L.P.; Mota, C.J.A. Direct Carbonation of Glycerol with $\mathrm{CO}_{2}$ Catalyzed by Metal Oxides. ChemPhysChem 2017, 18, 3260-3265. [CrossRef] [PubMed]

53. Teles, J.H.; Rieber, N.; Harder, W. Preparation of Glycerol Carbonate. US Patent 5359094A, 1994.

54. Hu, J.; Li, J.; Gu, Y.; Guan, Z.; Mo, W.; Ni, Y.; Li, T.; Li, G. Oxidative carbonylation of glycerol to glycerol carbonate catalyzed by PdCl2(phen)/KI. Appl. Catal. A Gen. 2010, 386, 188-193. [CrossRef]

55. Casiello, M.; Monopoli, A.; Cotugno, P.; Milella, A.; Dell'Anna, M.M.; Ciminale, F.; Nacci, A. Copper(II) chloride-catalyzed oxidative carbonylation of glycerol to glycerol carbonate. J. Mol. Catal. A Chem. 2013, 381, 99-106. [CrossRef]

56. Mizuno, T.; Nakai, T.; Mihara, M. New synthesis of glycerol carbonate from glycerol using sulfur-assisted carbonylation with carbon monoxide. Heteroat. Chem. 2010, 21, 99-102. [CrossRef]

57. Mizuno, T.; Nakai, T.; Mihara, M. Facile synthesis of glycerol carbonate from glycerol using selenium-catalyzed carbonylation with carbon monoxide. Heteroat. Chem. 2010, 21, 541-545. [CrossRef]

58. Hu, J.; Gu, Y.; Guan, Z.; Li, J.; Mo, W.; Li, T.; Li, G. An Efficient Palladium Catalyst System for the Oxidative Carbonylation of Glycerol to Glycerol Carbonate. ChemSusChem 2011, 4, 1767-1772. [CrossRef]

59. Doro, F.; Winnertz, P.; Leitner, W.; Prokofieva, A.; Müller, T.E. Adapting a Wacker-type catalyst system to the palladium-catalyzed oxidative carbonylation of aliphatic polyols. Green Chem. 2011, 13, 292-295. [CrossRef]

60. Pearson, D.M.; Conley, N.R.; Waymouth, R.M. Palladium-Catalyzed Carbonylation of Diols to Cyclic Carbonates. Adv. Synth . Catal. 2011, 353, 3007-3013. [CrossRef]

61. Li, J.; Wang, T. Chemical equilibrium of glycerol carbonate synthesis from glycerol. J. Chem. Thermodyn. 2011, 43, 731-736. [CrossRef]

62. Lukato, S.; Kasozi, G.N.; Naziriwo, B.; Tebandeke, E. Glycerol carbonylation with $\mathrm{CO}_{2}$ to form glycerol carbonate: A review of recent developments and challenges. Curr. Res. Green Sustain. Chem. 2021, 4, 100199. [CrossRef]

63. Na Lim, Y.; Lee, C.; Jang, H.-Y. ChemInform Abstract: Metal-Free Synthesis of Cyclic and Acyclic Carbonates from $\mathrm{CO}_{2}$ and Alcohols. ChemInform 2015, 46. [CrossRef] 
64. Podila, S.; Plasseraud, L.; Cattey, H.; Ballivet-Tkatchenko, D.; Carrera, G.V.S.M.; Nunes Da Ponte, M.; Neuberg, S.; Behr, A. Synthesis of 1,2-glycerol carbonate from carbon dioxide: The role of methanol in fluid phase equilibrium. Indian J. Chem. 2012, 51, 1330-1338.

65. Li, H.; Gao, D.; Gao, P.; Wang, F.; Zhao, N.; Xiao, F.; Wei, W.; Sun, Y. The synthesis of glycerol carbonate from glycerol and $\mathrm{CO}_{2}$ over $\mathrm{La}_{2} \mathrm{O}_{2} \mathrm{CO}_{3}-\mathrm{ZnO}$ catalysts. Catal. Sci. Technol. 2013, 3, 2801-2809. [CrossRef]

66. Zhang, J.; He, D. Synthesis of glycerol carbonate and monoacetin from glycerol and carbon dioxide over Cu catalysts: The role of supports. J. Chem. Technol. Biotechnol. 2015, 90, 1077-1085. [CrossRef]

67. Zhang, J.; He, D. Surface properties of $\mathrm{Cu} / \mathrm{La}_{2} \mathrm{O}_{3}$ and its catalytic performance in the synthesis of glycerol carbonate and monoacetin from glycerol and carbon dioxide. J. Colloid Interface Sci. 2014, 419, 31-38. [CrossRef] [PubMed]

68. Li, H.; Jiao, X.; Li, L.; Zhao, N.; Xiao, F.; Wei, W.; Sun, Y.; Zhang, B. Synthesis of glycerol carbonate by direct carbonylation of glycerol with $\mathrm{CO}_{2}$ over solid catalysts derived from $\mathrm{Zn} / \mathrm{Al} / \mathrm{La}$ and $\mathrm{Zn} / \mathrm{Al} / \mathrm{La} / \mathrm{M}(\mathrm{M}=\mathrm{Li}, \mathrm{Mg}$ and $\mathrm{Zr}$ ) hydrotalcites. Catal. Sci. Technol. 2015, 5, 989-1005. [CrossRef]

69. Honda, M.; Tamura, M.; Nakagawa, Y.; Nakao, K.; Suzuki, K.; Tomishige, K. Organic carbonate synthesis from $\mathrm{CO}_{2}$ and alcohol over $\mathrm{CeO}_{2}$ with 2-cyanopyridine: Scope and mechanistic studies. J. Catal. 2014, 318, 95-107. [CrossRef]

70. Bansode, A.; Urakawa, A. Continuous DMC Synthesis from $\mathrm{CO}_{2}$ and Methanol over a $\mathrm{CeO}_{2}$ Catalyst in a Fixed Bed Reactor in the Presence of a Dehydrating Agent. ACS Catal. 2014, 4, 3877-3880. [CrossRef]

71. Unnikrishnan, P.; Darbha, S. Direct synthesis of dimethyl carbonate from $\mathrm{CO}_{2}$ and methanol over $\mathrm{CeO}_{2}$ catalysts of different morphologies. J. Chem. Sci. 2016, 128, 957-965. [CrossRef]

72. Liu, J.; Li, Y.; Zhang, J.; He, D. Glycerol carbonylation with $\mathrm{CO}_{2}$ to glycerol carbonate over $\mathrm{CeO}_{2}$ catalyst and the influence of $\mathrm{CeO}_{2}$ preparation methods and reaction parameters. Appl. Catal. A Gen. 2016, 513, 9-18. [CrossRef]

73. Su, X.; Lin, W.; Cheng, H.; Zhang, C.; Wang, Y.; Yu, X.; Wu, Z.; Zhao, F. Metal-free catalytic conversion of $\mathrm{CO}_{2}$ and glycerol to glycerol carbonate. Green Chem. 2017, 19, 1775-1781. [CrossRef]

74. Zhang, Q.; Yuan, H.-Y.; Lin, X.-T.; Fukaya, N.; Fujitani, T.; Sato, K.; Choi, J.-C. Calcium carbide as a dehydrating agent for the synthesis of carbamates, glycerol carbonate, and cyclic carbonates from carbon dioxide. Green Chem. 2020, 22, 4231-4239. [CrossRef]

75. Collett, C.; Mašek, O.; Razali, N.; McGregor, J. Influence of Biochar Composition and Source Material on Catalytic Performance: The Carboxylation of Glycerol with $\mathrm{CO}_{2}$ as a Case Study. Catalysts 2020, 10, 1067. [CrossRef]

76. Razali, N.; McGregor, J. Improving Product Yield in the Direct Carboxylation of Glycerol with $\mathrm{CO}_{2}$ through the Tailored Selection of Dehydrating Agents. Catalysts 2021, 11, 138. [CrossRef]

77. Hu, C.; Yoshida, M.; Chen, H.-C.; Tsunekawa, S.; Lin, Y.-F.; Huang, J.-H. Production of glycerol carbonate from carboxylation of glycerol with $\mathrm{CO}_{2}$ using ZIF-67 as a catalyst. Chem. Eng. Sci. 2021, 235, 116451. [CrossRef]

78. Li, Y.; Liu, H.; Ma, L.; Liu, J.; He, D. Transforming glycerol and $\mathrm{CO}_{2}$ into glycerol carbonate over $\mathrm{La}_{2} \mathrm{O}_{2} \mathrm{CO}_{3}-\mathrm{ZnO}_{\text {catalyst}-\mathrm{A}}$ case study of the photo-thermal synergism. Catal. Sci. Technol. 2021, 11, 1007-1013. [CrossRef]

79. Ochoa-Gómez, J.R.; Gómez-Jiménez-Aberasturi, O.; Maestro-Madurga, B.; Pesquera-Rodríguez, A.; Ramírez-López, C.; LorenzoIbarreta, L.; Torrecilla-Soria, J.; Villarán-Velasco, M.C. Synthesis of glycerol carbonate from glycerol and dimethyl carbonate by transesterification: Catalyst screening and reaction optimization. Appl. Catal. A Gen. 2009, 366, 315-324. [CrossRef]

80. Sahani, S.; Upadhyay, S.N.; Sharma, Y.C. Critical Review on Production of Glycerol Carbonate from Byproduct Glycerol through Transesterification. Ind. Eng. Chem. Res. 2020, 60, 67-88. [CrossRef]

81. Climent, M.J.; Corma, A.; De Frutos, P.; Iborra, S.; Noy, M.; Velty, A.; Concepción, P. Chemicals from biomass: Synthesis of glycerol carbonate by transesterification and carbonylation with urea with hydrotalcite catalysts. The role of acid-base pairs. J. Catal. 2010, 269, 140-149. [CrossRef]

82. Cho, H.J.; Kwon, H.M.; Jose, T.; Park, D.W. Synthesis of glycerol carbonate from ethylene carbonate and glycerol using immobilized ionic liquid catalysts. J. Ind. Eng. Chem. 2010, 16, 679-683. [CrossRef]

83. Lanjekar, K.; Rathod, V.K. Utilization of glycerol for the production of glycerol carbonate through greener route. J. Environ. Chem. Eng. 2013, 1, 1231-1236. [CrossRef]

84. Liu, P.; Derchi, M.; Hensen, E.J. Synthesis of glycerol carbonate by transesterification of glycerol with dimethyl carbonate over MgAl mixed oxide catalysts. Appl. Catal. A Gen. 2013, 467, 124-131. [CrossRef]

85. Gmehling, J.; Menke, J.; Krafczyk, J.; Fischer, J.; Fontaine, J.-C.; Kehiaian, H.V. Azeotropic Data for Binary Mixture. In Handbook of Chemistry and Physics; CRC Press LLC: Boca Raton, FL, USA, 2011; Volume 6.

86. Sandesh, S.; Shanbhag, G.V.; Halgeri, A.B. Transesterification of Glycerol to Glycerol Carbonate Using $\mathrm{KF} / \mathrm{Al}_{2} \mathrm{O}_{3} \mathrm{Catalyst:} \mathrm{The}$ Role of Support and Basicity. Catal. Lett. 2013, 143, 1226-1234. [CrossRef]

87. Bai, R.; Wang, Y.; Wang, S.; Mei, F.; Li, T.; Li, G. Synthesis of glycerol carbonate from glycerol and dimethyl carbonate catalyzed by $\mathrm{NaOH} / \gamma-\mathrm{Al}_{2} \mathrm{O}_{3}$. Fuel Process. Technol. 2013, 106, 209-214. [CrossRef]

88. Ramesh, S.; Debecker, D.P. Room temperature synthesis of glycerol carbonate catalyzed by spray dried sodium aluminate microspheres. Catal. Commun. 2017, 97, 102-105. [CrossRef]

89. Ramesh, S.; Devred, F.; Biggelaar, L.V.D.; Debecker, D.P. Hydrotalcites Promoted by $\mathrm{NaAlO}_{2}$ as Strongly Basic Catalysts with Record Activity in Glycerol Carbonate Synthesis. ChemCatChem 2018, 10, 1398-1405. [CrossRef] 
90. Rittiron, P.; Niamnuy, C.; Donphai, W.; Chareonpanich, M.; Seubsai, A. Production of Glycerol Carbonate from Glycerol over Templated-Sodium-Aluminate Catalysts Prepared Using a Spray-Drying Method. ACS Omega 2019, 4, 9001-9009. [CrossRef] [PubMed]

91. Chotchuang, A.; Kunsuk, P.; Phanpitakkul, A.; Chanklang, S.; Chareonpanicha, M.; Seubsai, A. Production of glycerol car-bonate from glycerol over modified sodium-aluminate-doped calcium oxide catalysts. Catal. Today 2020, in press. [CrossRef]

92. Li, J.; Wang, T. On the deactivation of alkali solid catalysts for the synthesis of glycerol carbonate from glycerol and dimethyl carbonate. React. Kinet. Mech. Catal. 2011, 102, 113-126. [CrossRef]

93. Li, J.; Wang, L. Coupling reaction and azeotropic distillation for the synthesis of glycerol carbonate from glycerol and dimethyl carbonate. Chem. Eng. Process. 2010, 49, 530-535. [CrossRef]

94. Oprescu, E.E.; Stepan, E.; Rosca, P.; Radu, A.; Enascuta, C.E. Synthesis of glycerol carbonate over hydrotalcite catalyst. Rev. Chem. 2012, 63, 621-625.

95. Guanhao Liu, G.; Yang, J.; Xu, X. Synthesis of hydrotalcite-type mixed oxide catalysts from waste steel slag for transesterification of glycerol and dimethyl carbonate. Sci. Rep. 2020, 10, 10273.

96. Granados-Reyes, J.; Salagre, P.; Cesteros, Y. Effect of the preparation conditions on the catalytic activity of calcined Ca/Al-layered double hydroxides for the synthesis of glycerol carbonate. Appl. Catal. A Gen. 2017, 536, 9-17. [CrossRef]

97. Song, X.; Wu, Y.; Cai, F.; Pan, D.; Xiao, G. High-efficiency and low-cost Li/ZnO catalysts for synthesis of glycerol carbonate from glycerol transesterification: The role of Li and ZnO interaction. Appl. Catal. A Gen. 2017, 532, 77-85. [CrossRef]

98. Algoufi, Y.T.; Kabir, G.; Hameed, B.H. Synthesis of glycerol carbonate from biodiesel by-product glycerol over calcined dolomite. J. Taiwan Inst. Chem. Eng. 2017, 70, 179-187. [CrossRef]

99. Algoufi, Y.; Akpan, U.; Kabir, G.; Asif, M.; Hameed, B. Upgrading of glycerol from biodiesel synthesis with dimethyl carbonate on reusable Sr-Al mixed oxide catalysts. Energy Convers. Manag. 2017, 138, 183-189. [CrossRef]

100. Kaur, A.; Ali, A. Lithium Zirconate as a Selective and Cost-Effective Mixed Metal Oxide Catalyst for Glycerol Carbonate Production. Ind. Eng. Chem. Res. 2020, 59, 2667-2679. [CrossRef]

101. Arora, S.; Gosu, V.; Kumar, U.A.; Subbaramaiah, V. Valorization of glycerol into glycerol carbonate using the stable heterogeneous catalyst of Li/MCM-41. J. Clean. Prod. 2021, 295, 126437. [CrossRef]

102. Zhang, P.; Chen, Y.; Zhu, M.; Yue, C.; Dong, Y.; Leng, Y.; Fan, M.; Jiang, P. Acidic-Basic Bifunctional Magnetic Mesoporous $\mathrm{CoFe}_{2} \mathrm{O}_{4} @(\mathrm{CaO}-\mathrm{ZnO})$ for the Synthesis of Glycerol Carbonate. Catal. Lett. 2020, 150, 2863-2872. [CrossRef]

103. Praikaew, W.; Kiatkittipong, W.; Aiouache, F.; Najdanovic-Visak, V.; Ngaosuwan, K.; Wongsawaeng, D.; Lim, J.; Lam, S.; Kiatkittipong, K.; Laosiripojana, N.; et al. Process and Energy Intensification of Glycerol Carbonate Production from Glycerol and Dimethyl Carbonate in the Presence of Eggshell-Derived CaO Heterogeneous Catalyst. Energies 2021, 14, 4249. [CrossRef]

104. Pattanaik, P.P.; Kumar, P.M.; Raju, N.; Lingaiah, N. Continuous Synthesis of Glycerol Carbonate by Transesterification of Glycerol with Dimethyl Carbonate Over Fe-La Mixed Oxide Catalysts. Catal. Lett. 2020, 151, 1433-1443. [CrossRef]

105. Arora, S.; Gosu, V.; Subbaramaiah, V. One-pot synthesis of glycerol carbonate from glycerol using three-dimensional meso-porous silicates of K/TUD-1 under environmentally benign conditions. Mol. Catal. 2020, 496, 111188. [CrossRef]

106. Tudorache, M.; Negoi, A.; Tudora, B.; Parvulescu, V.I. Environmental-friendly strategy for biocatalytic conversion of waste glycerol to glycerol carbonate. Appl. Catal. B Environ. 2014, 146, 274-278. [CrossRef]

107. Lee, K.H.; Park, C.H.; Lee, E.Y. Synthesis of glycerol 1,2-carbonate by transesterification of glycerol with dimethyl carbonate using triethylamine as a facile separable homogeneous catalyst. Bioproc. Biosyst. Eng. 2010, 33, 1059-1065. [CrossRef]

108. Waghmare, G.V.; Vetal, M.D.; Rathod, V.K. Ultrasound assisted enzyme catalyzed synthesis of glycerol carbonate from glycerol and dimethyl carbonate. Ultrason. Sonochemistry 2015, 22, 311-316. [CrossRef] [PubMed]

109. Du, Y.; Gao, J.; Kong, W.; Zhou, L.; Ma, L.; He, Y.; Huang, Z.; Jiang, Y. Enzymatic Synthesis of Glycerol Carbonate Using a Lipase Immobilized on Magnetic Organosilica Nanoflowers as a Catalyst. ACS Omega 2018, 3, 6642-6650. [CrossRef] [PubMed]

110. Selva, M.; Perosa, A.; Guidi, S.; Cattelan, L. Ionic liquids as transesterification catalysts: Applications for the synthesis of linear and cyclic organic carbonates. Beilstein J. Org. Chem. 2016, 12, 1911-1924. [CrossRef]

111. Wang, X.; Zhang, P.; Cui, P.; Cheng, W.; Zhang, S. Glycerol carbonate synthesis from glycerol and dimethyl carbonate using guanidine ionic liquids. Chin. J. Chem. Eng. 2017, 25, 1182-1186. [CrossRef]

112. Simanjuntak, F.S.H.; Choi, S.J.; Lee, G.; Lee, S.D.; Cheong, M.; Kim, S.H.; Lee, H. Synthesis of glycerol carbonate from the transesterification of dimethyl carbonate with glycerol using DABCO and DABCO-anchored Merrifield resin. Appl. Catal. B Environ. 2015, 165, 642-650. [CrossRef]

113. Yi, Y.; Shen, Y.; Sun, J.; Wang, B.; Xu, F.; Sun, R. Basic ionic liquids promoted the synthesis of glycerol 1,2-carbonate from glycerol. Chin. J. Catal. 2014, 35, 757-762. [CrossRef]

114. Guzmán-Lucero, D.; Castillo-Acosta, S.; Martínez-Palou, R. Glycerol Carbonate Synthesis Using Poly(1-alkyl-3-vinylimidazolium) Imidazolates as Catalysts. ChemistrySelect 2020, 5, 13694-13702. [CrossRef] 